\title{
Cellulose-Based Nanofibril Composite Materials as a New Approach to Fight Bacterial Infections
}

\begin{abstract}
Somaye Rashki ${ }^{1}$, Neda Shakour ${ }^{2,3}$, Zahra Yousefi ${ }^{4}$, Marzieh Rezaei $^{5}$, Mina Homayoonfal ${ }^{6}$, Ehsan Khabazian ${ }^{7}$, Fatemeh Atyabi ${ }^{7,8}$, Fatemeh Aslanbeigi ${ }^{9,10}$, Rouzita Safaei Lapavandani ${ }^{11}$, Samaneh Mazaheri ${ }^{12 *}$, Michael R Hamblin ${ }^{13 *}$ and Hamed Mirzaei ${ }^{6 *}$

${ }^{1}$ Department of Microbiology and Immunology, Faculty of Medicine, Kashan University of Medical Sciences, Kashan, Iran, ${ }^{2}$ Department of Medicinal Chemistry, School of Pharmacy, Mashhad University of Medical Sciences, Mashhad, Iran, ${ }^{3}$ Student Research Committee, Faculty of Medicine, Mashhad University of Medical Sciences, Mashhad, Iran, ${ }^{4}$ School of Allied Medical Sciences, Shahroud University of Medical Sciences, Shahroud, Iran, ${ }^{5}$ Department of Medical Biotechnology and Nanotechnology, Faculty of Medicine, Mashhad University of Medical Sciences, Mashhad, Iran, ${ }^{6}$ Research Center for Biochemistry and Nutrition in Metabolic Diseases, Institute for Basic Sciences, Kashan University of Medical Sciences, Kashan, Iran, ${ }^{7}$ Department of Pharmaceutics, Faculty of Pharmacy, Tehran University of Medical Sciences, Tehran, Iran, ${ }^{8}$ Nanotechnology Research Centre, Faculty of Pharmacy, Tehran University of Medical Sciences, Tehran, Iran, ${ }^{9}$ School of Medicine, Kashan University of Medical Sciences, Kashan, Iran, ${ }^{10}$ Student Research Committee, Kashan University of Medical Sciences, Kashan, Iran, ${ }^{11}$ Department of Gynecology and Obsteterics, Shaheed Beheshti University of Medical Sciences, Tehran, Iran,

${ }^{12}$ Department of Analytical Chemistry, Faculty of Chemistry, University of Kashan, Kashan, Iran, ${ }^{13}$ Laser Research Centre, Faculty of Health Science, University of Johannesburg, Doornfontein, South Africa
\end{abstract}

Antibiotic resistant microorganisms have become an enormous global challenge, and are predicted to cause hundreds of millions of deaths. Therefore, the search for novel/ alternative antimicrobial agents is a grand global challenge. Cellulose is an abundant biopolymer with the advantages of low cost, biodegradability, and biocompatibility. With the recent growth of nanotechnology and nanomedicine, numerous researchers have investigated nanofibril cellulose to try to develop an anti-bacterial biomaterial. However, nanofibril cellulose has no inherent antibacterial activity, and therefore cannot be used on its own. To empower cellulose with anti-bacterial properties, new efficient nanomaterials have been designed based on cellulose-based nanofibrils as potential wound dressings, food packaging, and for other antibacterial applications. In this review we summarize reports concerning the therapeutic potential of cellulose-based nanofibrils against various bacterial infections

Keywords: cellulose, nanofibrils, antimicrobial activity, bacterial infections, nanotechnology

\section{INTRODUCTION}

Infections caused by antibiotic-resistant bacteria are now a serious worldwide challenge to public health, causing unacceptable morbidity, mortality, and expense to society. For several decades, the number of infections associated with antibiotic resistant bacteria has steadily increased (Wang, Hu et al., 2017). Consequently, novel methods must be devised to destroy microbes in a more environmentally friendly manner. Towards this goal, nanomaterials have been widely explored to generate new antimicrobial agents (Martins, Freire et al., 2012). Nanoscale materials have shown great promise for reducing the growth of antibiotic resistance in general (Zille, Almeida et al., 2014). However, the development of antimicrobial materials is faced with multiple problems. The development of suitably biodegradable and biocompatible 


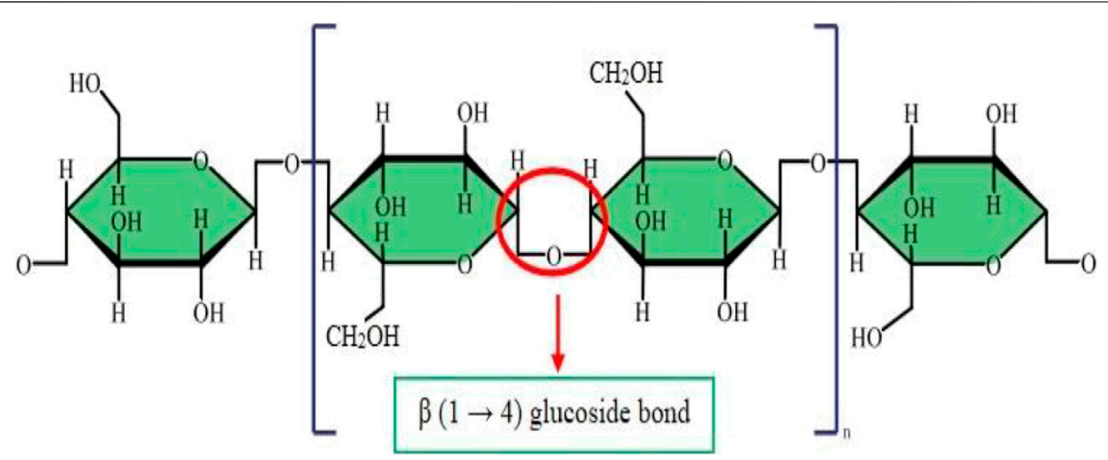

FIGURE 1 | Molecular structure of cellulose.

surfaces with prolonged anti-bacterial activity, at a comparatively low cost has not yet been achieved (Council 2006; Tavakolian, Jafari et al., 2020). Cellulose is an abundant biopolymer widely used as a reinforcing component in fiber-based thermo-plastic composite materials. Cellulose is regarded as an almost unlimited natural resource, which could help to meet the increasing demand for more biocompatible and biodegradable products. Cellulose is a natural biopolymer, that can take the form of cellulose nanofibers (CNF) or fibrils varying from 50 to $60 \mathrm{~nm}$ in diameter. These can be used to generate nanostructured paper sheets, thin films, multifunctional nanocomposites, or translucent films (Kalia, Dufresne et al., 2011; Moohan, Stewart et al., 2020; Zeng, Zeng et al., 2021). These structures show low gas-barrier properties, along with other advantages (Abe, Iwamoto et al., 2007). The use of naturally derived nano-biopolymers can reduce their possible toxicity and widen their applicability. However, it has been found that cellulose in its natural state does not possess any intrinsic antibacterial activity. Nevertheless, it does possess an abundance of functional groups that may be chemically modified for a variety of applications (Tavakolian, Jafari et al., 2020). These materials can have powerful and long-lasting antimicrobial activity, which is resistant to leaching within the biological environment. In fact, their unique advantage over other antibacterial materials results from the nonleaching action, where the bacteria are required to be in direct contact with the surface (Hassan, Forsman et al., 2020). Nevertheless, such materials have been considered to be useful alternatives in situations where this direct contact occurs automatically, such as water purification, anti-bacterial filters, food packaging, wound dressings, and anti-bacterial coatings used in health care environments to avoid cross-infection between patients and hospital spread. This review discusses the therapeutic potential of cellulose-based nanofibrils against various bacterial species and infections. Also, in this review, we summarize the properties and anti-bacterial activity of cellulose, and the preparation of cellulose-based nanofibrils.

\section{CELLULOSE PROPERTIES AND ANTI-BACTERIAL ACTIVITY}

As mentioned earlier, cellulose is the most plentiful organic material on the planet earth. Nearly a billion tons of cellulose is produced from different plants annually (Kafy, Kim et al., 2017). Cellulose is composed of a linear polymer chain made up of glucose monomers with the formula $\left(\mathrm{C}_{6} \mathrm{H}_{10} \mathrm{O}_{5}\right)_{n}$ (Figure 1) and called poly- $\beta$-1,4-linked anhydro-D-glucose. Moreover, the linear cellulose chains can form supramolecular assemblies by formation of hydrogen bonds between neighboring hydroxyl groups of adjacent cellulose chains. Therefore, cellulose can produce a regular networked macrostructure. The growth of nanotechnology has led to the investigation of nanocellulose as a new versatile biomaterial (Lin and Dufresne 2014). Nanocellulose is produced from natural renewable sources, such as plants (wood and grasses) as well as bacterial cellulose. Nanocellulose contains repeating $\beta-1,4$ linked d-glucose units, each with three active hydroxyl groups at the $\mathrm{C} 2, \mathrm{C} 3$, and C6 positions of the glucopyranose ring ( $\mathrm{Li}$, Cha et al., 2018). The nano-cellulose family may be divided into three broad groupings of materials (Ullah, Manan et al., 2021) (Figure 2).

One growing application of CNFs is in the development of novel antibacterial materials based on cellulose. In contrast to other natural bio-polymers such as chitosan $(\mathrm{CH})$, that exhibit intrinsic antimicrobial activity, cellulose is not considered to be intrinsically antimicrobial (Tavakolian, Okshevsky et al., 2018). Hence, cellulose requires to be chemically modified to become an effective antimicrobial agent. Because there are multiple reactive hydroxyl groups on the surface of cellulose fibrils, they can react with carboxylic acids, amines, or aldehydes, to change the properties of the polymer (Tavakolian, Jafari et al., 2020). There are four main methods for the preparation of antimicrobial materials based on nanocellulose, including modifying the surface, adding antibiotics, combining with other nanomaterials, or combining with other antibacterial agents (Saini, Belgacem et al., 2015; Anirudhan and Deepa 2017; Singla, Soni et al., 2017). For instance, chemical attachment of aminoalkyl groups to the cellulose surface promoted the lethal activity of cellulose against $S$. aureus (Saini, Belgacem et al., 2017). Moreover, the antibacterial activity of CNF was increased by increasing the alkyl chain length of the aminoalkyl groups (Figure 3). Besides the alkyl chain length, increasing the number of amino groups can also improve the antibacterial activity (Kim, Choi et al., 1997). In one study, Jiang et al., functionalized cellulose by the introduction of 


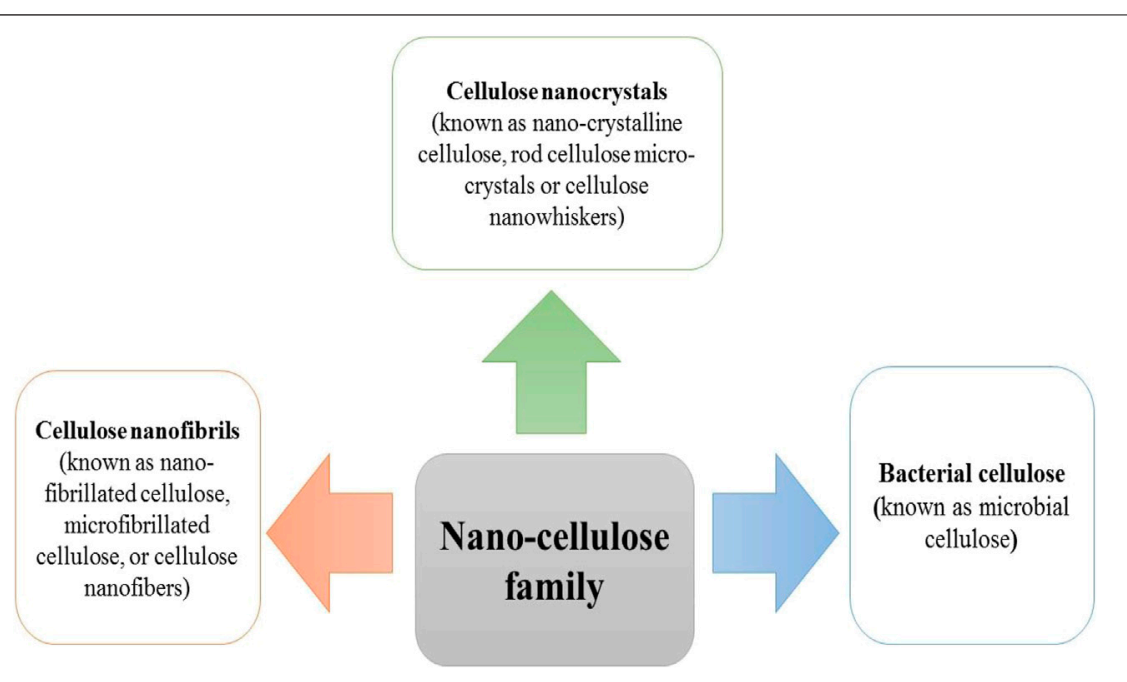

FIGURE 2 | The family of nano-cellulose structures.

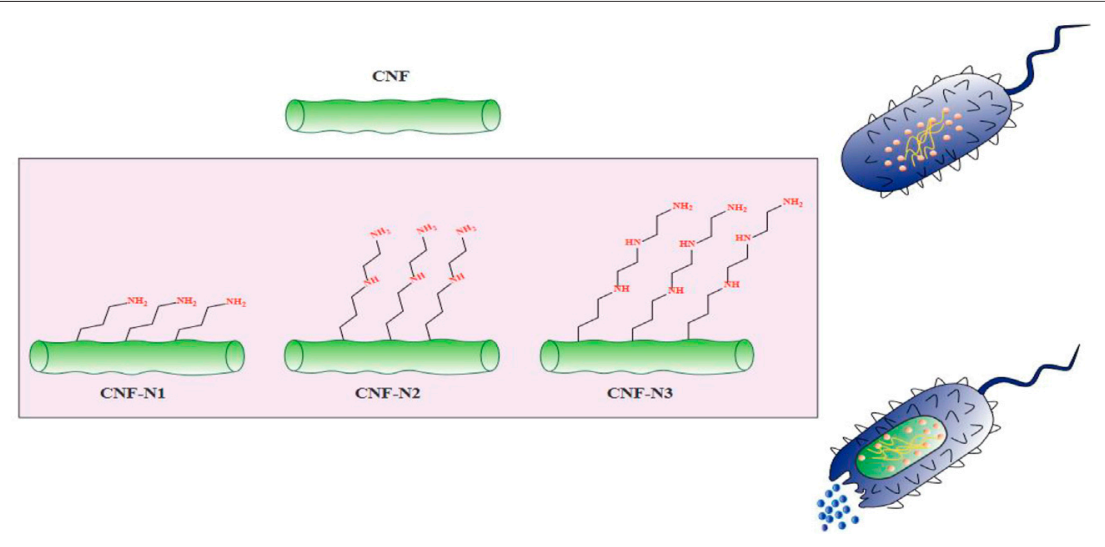

FIGURE 3 | The antibacterial activity of aminoalkyl grafted CNF. This figure adapted from Saini et al. (Saini, Belgacem et al., 2017).

$\mathrm{N}$-halamines (chloro- or bromoamines) to the CNC backbone via reaction with the hydroxyl groups (Jiang, Qiao et al., 2017). The mechanism of action of $\mathrm{N}$-halamines is the direct reaction of halogen atoms such as $\mathrm{Br}-$ or $\mathrm{Cl}-$ with the amino or thiol groups of the proteins present on the bacterial cells, leading to inactivation or growth inhibition (Kocer, Akdag et al., 2008). In addition, aldehyde-modified nanofibrillated cellulose showed antibacterial activity against MRSA (methicillin-resistant $S$. aureus). The action mechanism for aldehyde-modified nanofibrillated cellulose was to increase the acidic environment for the bacteria due to the presence of dialdehyde groups (Tavakolian, Jafari et al., 2020). Antimicrobial materials based on nanocellulose can also be employed in other applications, such drug carriers, packaging materials, and wound dressings (Li, Cha et al., 2018).

Recently, polymers extracted from plants, such as pectin and cellulose, have attracted much attention for the synthesis and modification of metal oxide nanoparticles (MONPs) and metal nanoparticles (MNPs). The antibacterial and anti-infective properties of nanoparticles (NPs) can be enhanced using the antimicrobial properties of primary and secondary metabolites obtained from these herbal sources. Among the MONPs/MNPs investigated, $\mathrm{Ag}, \mathrm{CuO}, \mathrm{ZnO}$, and $\mathrm{Cu}$ NPs have exhibited more potent antimicrobial properties due to their ability to produce reactive oxygen species (ROS) (Alavi and Kennedy 2021). The encapsulation and loading of AgNPs by cellulose nanostructures can decrease the side effects of argyrosis or argyria, sometimes observed in patients. In one comparison study, $10 \mathrm{wt} \%$ and $5 \mathrm{wt} \%$ of $\mathrm{AgNP} / \mathrm{TiO}_{2} \mathrm{NPs}$ were loaded onto cellulose acetate (CA) nanofibers (CNFs) to produce $\mathrm{CA} / \mathrm{TiO}_{2} / \mathrm{AgNP}-2$ and $\mathrm{CA} /$ $\mathrm{TiO}_{2} /$ AgNP-1, respectively. The order of antibacterial activity and growth inhibition after $24 \mathrm{~h}$ incubation for both $E$. coli and $S$. aureus were as follows: $\mathrm{CA} / \mathrm{TiO}_{2} / \mathrm{AgNP}-2$ > $\mathrm{CA} / \mathrm{TiO}_{2} / \mathrm{AgNP}-1$ > $\mathrm{CA} / \mathrm{TiO}_{2}$ > CA (Kim et al., 2011; Jatoi et al., 2019b). The precise bacterial strain and the physicochemical properties of the MNP/ MONP may influence the antibacterial activity. CuNPs and 
AgNPs were prepared respectively by chemical reduction and ultraviolet radiation methods, followed by immobilization onto CNFs. Potent bactericidal activity against B. subtilis (Grampositive bacteria) and E. coli (Gram-negative bacteria) was reported for $\mathrm{Cu} / \mathrm{CNFs}$ and $\mathrm{Ag} / \mathrm{CNF}$, respectively (Phan, Dorjjugder et al., 2019). Chemical (CD) and mechanical (MD) techniques were used to deposit AgNPs onto ZnONPs to form nanocomposites (NCs). The process was followed by capping the NCs with carboxymethyl cellulose (CMC), to produce CMC-Ag$\mathrm{ZnO}$ NCs. More potent antibacterial properties were reported for $\mathrm{Ag}-\mathrm{ZnO} \mathrm{NCs}$ (CD) compared to AgZnO NCs (MD). For example, MRSA showed 16 and $18 \mathrm{~mm}$ zones of inhibition for Ag-ZnO NCs (MD) and Ag-ZnO NCs (CD), respectively (Lungu, Vasile et al., 2016).

\section{PREPARATION OF CELLULOSE-BASED NANOFIBRILS}

Currently, nanofibrillated cellulose can be produced from several different cellulosic resources. Most studies have used wood as the most important industrial natural resource for production of cellulosic fibers (Missoum, Belgacem et al., 2013). It is possible to employ different techniques for extracting the cellulose nanofibers from wood and other bulk cellulose sources.

\section{Biological Methods}

Biological techniques can be used to disrupt the crystalline structure of the cellulose nanofibrils, for example enzymeassisted hydrolysis (Hayashi and Kondo 2015), as well as mild mechanical methods (Iwamoto, Kai et al., 2010), or a combination of these two treatments (Hubbe, Rojas et al., 2008). Enzymatic hydrolysis is an effective technique that uses a purified endoglucanase to promote defibrillation. It results in the specific hydrolysis of the glucosidic bonds along the cellulose chain, mainly in less crystalline domains (Moon, Martini et al., 2011). Lignin, cross-linked polysaccharide networks, and glycosylated proteins are all components of plant cell walls. Lignin can reinforce hemicellulose and cellulose microfilms, just like steel rods firmly implanted in concrete. Pretreatment can reduce this reinforcement, thus biomaterials, chemicals or enzymes can be more easily in contact with each other and therefore able to generate more effective products. The pretreatment process can improve the directly accessible surface area (ASA), thereby increasing the cellulose availability. Different sub-steps are involved with different pretreatments, which can improve the overall digestion. However, the higher accessibility of the cellulose can change the physical structure and chemical composition. This preparation of nanocrystals from bacterial cellulose does not involve dangerous chemical reagents, so it is a green production method (Zhang, Barhoum et al., 2019).

Microbial sources of CNC, including fungi, bacteria, and other microorganisms, provide fibers with an individual diameter of $2 \mathrm{~nm}$, which form a nanofiber bunch or bundle with a diameter of approximately $100 \mathrm{~nm}$. These fibers have useful inherent properties with a crystallinity percentage around $84-89 \%$ (Thomas, Paul et al., 2011).

One of the main challenges in the formulation of nanocellulose structures is the need to combine hydrophilic nanocellulose with hydrophobic polymers, leading to problems with mixing of the components and aggregation. Therefore, there will be a possibility of forming a non-dispersed matrix structure, with the loss of the reinforcing nanoscale properties. The hydrophobic nature of the nanocellulose composite may be circumvented in the presence of polar organic solvents like $\mathrm{N}$-methyl pyrrolidone, dimethyl sulfoxide, or N,N-dimethyl formamide (Dufresne 2013). Low yields of products with a wide range of sizes have been reported for existing techniques. Hence, there is a need to improve on these methods for large scale industrial purposes or commercialization. Pre-treatment techniques have often been suggested as the best strategies for greater efficiency. The production of nanocellulose products using enzymes is often carried out in industrial processes. The production of nanocellulose using enzymatic treatments is so important that it has motivated many researchers to study this approach. The production of nanocellulose using enzymatic hydrolysis is a multi-step process. The first step involves the pretreatment of the lignocellulosic biomass. The second and most important step involves controlled enzymatic hydrolysis of the fibers. The third step consists of homogenization of the enzyme-treated materials by washing, suspension, or mechanical homogenization. Fabricated nanocellulose products can be prepared with a uniform consistency using these optimized methods (Ribeiro, Pohlmann et al., 2019). The drawbacks of the enzymatic hydrolysis method are the longer time and expensive enzymes that are needed (Ribeiro, Pohlmann et al., 2019). Accordingly, research laboratories and industrial companies have focused in recent years on reducing these costs by improving the saccharification efficiency, increasing the permeability of the bulk material, and reducing environmental pollution.

\section{Mechanical Methods}

Physical or mechanical extraction procedures include highpressure homogenization, cryocrushing, microfluidization, and grinding (Figure 4). The fibers produced by these procedures have low stability and a variable ratio of length to diameter due to the application of higher fiber tension (Lavoine, Desloges et al., 2012). The other drawback of the procedure has been proposed to be its relatively unpredictable effects. Depending on the mechanical treatment and the level of mechanical force, the breaking of hydrogen bonds between the adjacent fibrils can occur. Mechanical methods can be costly (materials and instrumentation), have lower effectiveness, and consume more energy than chemical methods. A chemical pretreatment can decrease the consumption of energy and can also increase the surface hydrophobicity. Furthermore, mechanical treatments can decrease the DP (degree of polymerization) and polymer length from $1,200-1,400$ to between 850 and 500 glucose monomers. Moreover, the DP can affect the nanofiber tensile resistance that may be nearly as high 2 Gpa (Rojas, Bedoya et al., 2015). 

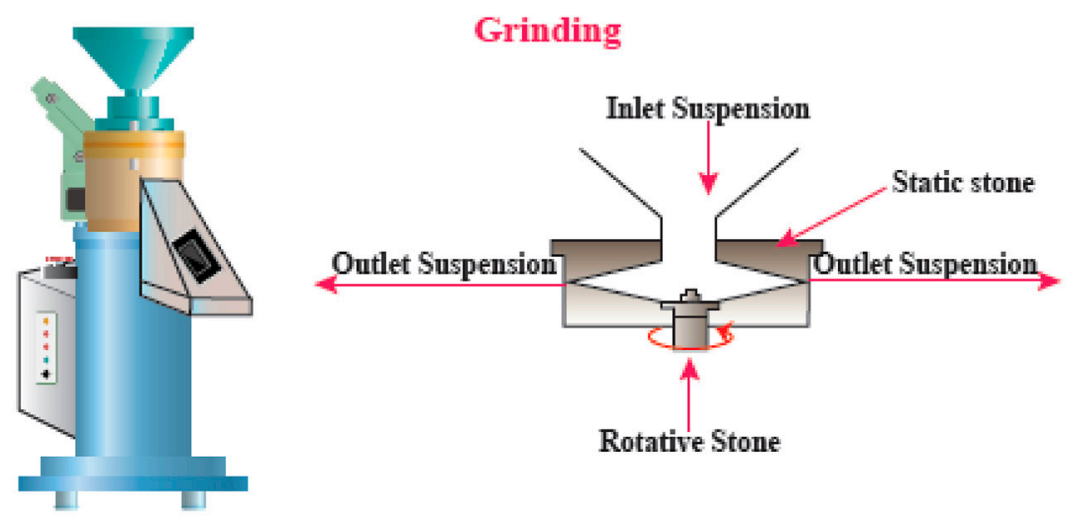

Grinding

High Pressure Homogenizer
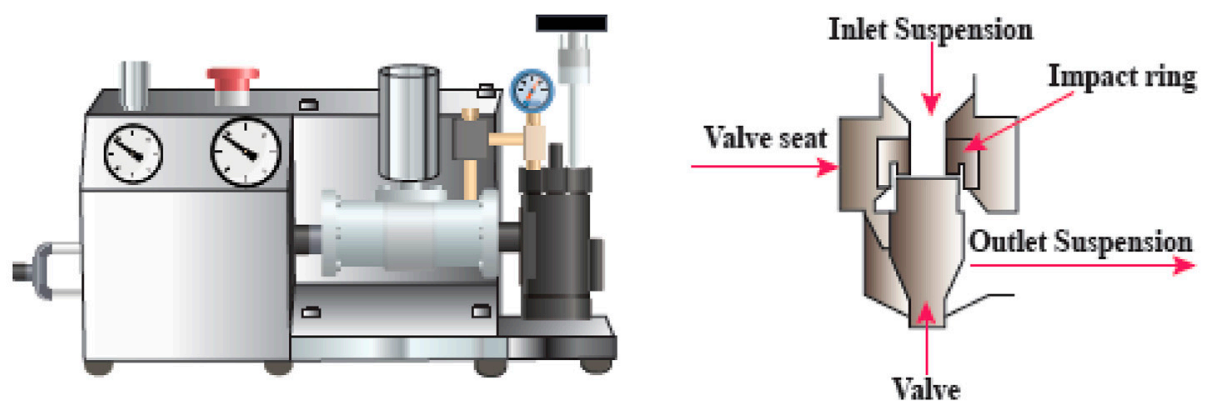

\section{Microfluidizer}

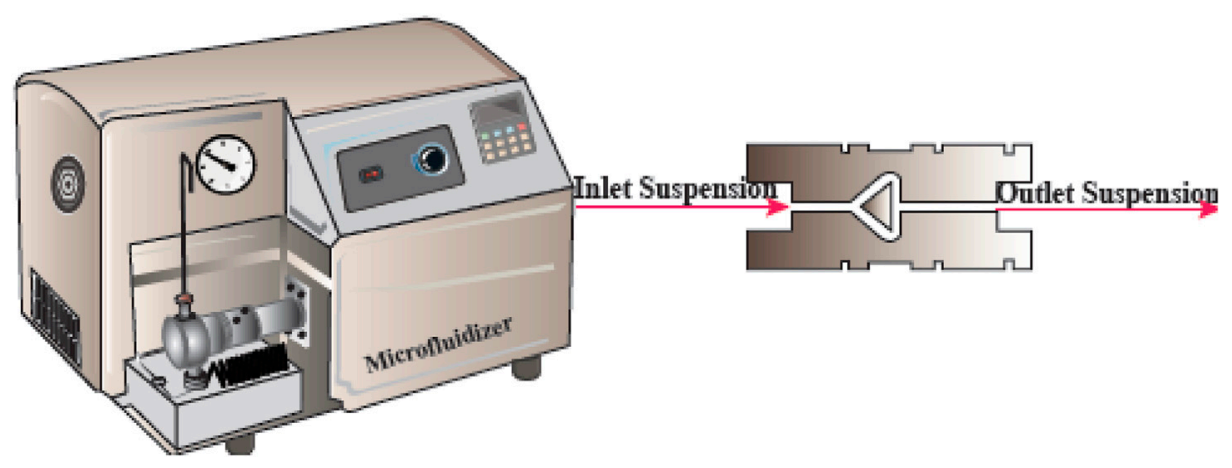

FIGURE 4 | Mechanical methods for CNF production. This figure adapted from www.niro-soavi.com, www.microfluidicscorp.com and www.masuko.com.

\section{High-Pressure Homogenization (HPH)}

The HPH procedure involves passing a cellulose suspension through a narrow nozzle at high pressure into a container. The high pressure and velocity and the impact produce shear forces within the fluid, causing shear rates to increase and reducing the size of the fibers to the nanoscale. The advantages of HPH are its simplicity, high efficiency, and no need for organic solvents. The first application of the HPH process to generate NFC from wood pulp was reported in 1983 (Abdul Khalil et al., 2014).

\section{Microfluidizer}

A progressively higher velocity can be obtained when the cellulose suspension is passed at high pressure through geometrically designed microchannels (Figure 5). Therefore, researchers employed a narrow Z-shaped enclosure with decreasing dimensions of 400-200-100 $\mu \mathrm{m}$ for fibrillation production. The lower the dimensions of the enclosure, the greater the degree of fibrillation. At the end of this process, a heat exchanger is employed to cool the product stream to the environmental temperature (Missoum, Belgacem et al., 2013). 


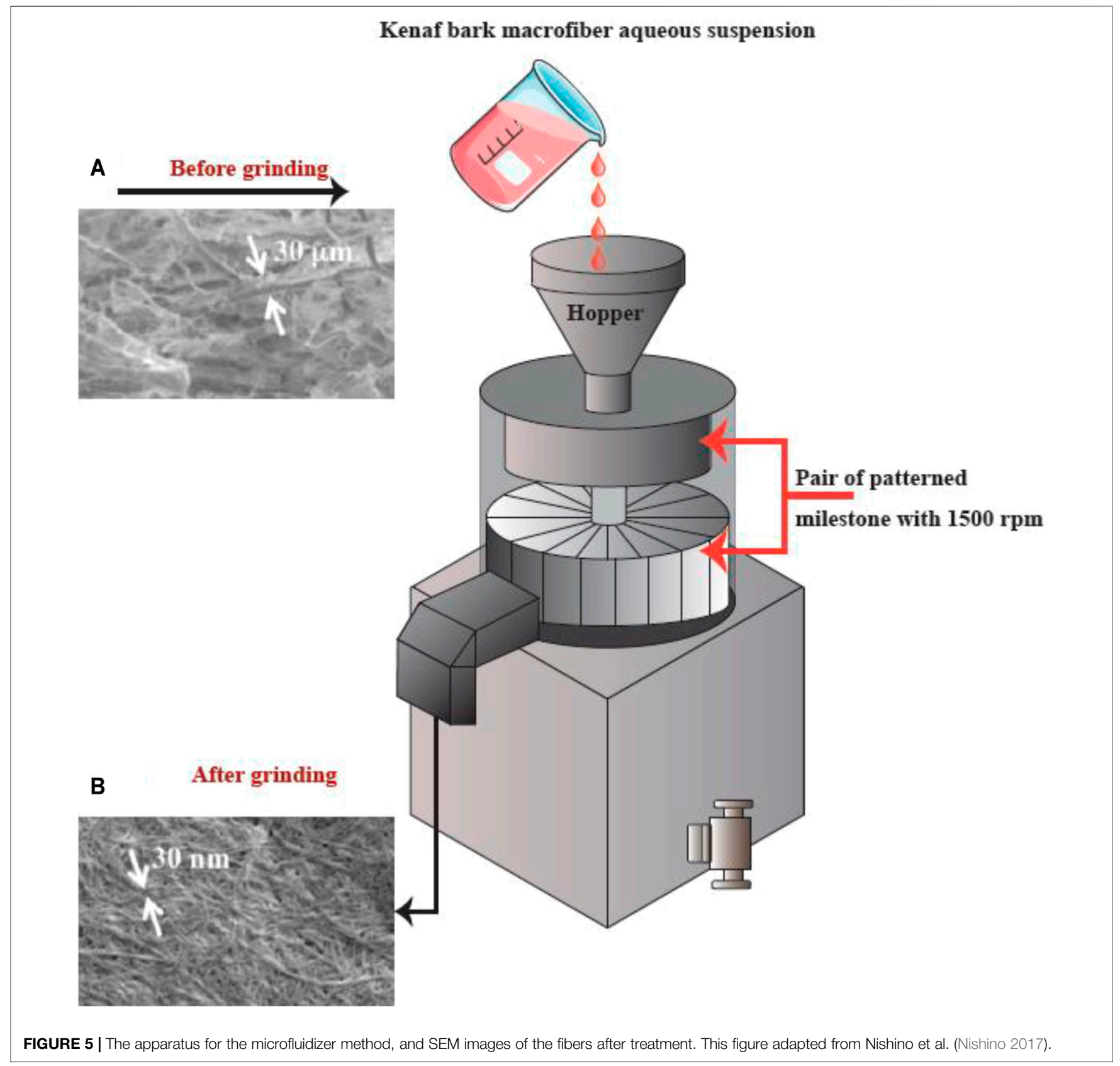

\section{Grinding}

Grinding is another method that can be used for breaking up cellulose into nanofibers (Figure 6). The grinding equipment consists of a rotating and a static grindstone, where a slurry of wood pulp is pumped between both the grindstones. Therefore, the mechanism of fibrillation by grinding, is the break-down of the structure of the cell walls and the interchain hydrogen bonds through shear force which converts the pulp to nanofibers (Abdul Khalil et al., 2014).

\section{Cryocrushing}

In this procedure, the cellulosic fibers are swollen in water, and then submerged in liquid nitrogen, followed and afterward are shattered by pestle and mortar. The application of force on the frozen cellulosic fibers caused the rupture of the cell walls, because of the extra pressure exerted by the ice crystals thus producing the nanofibers. In this regard, Wang and Sain generated nanofibers from soybean waste products by a high pressure defibrillation process followed by cryocrushing (Abdul Khalil et al., 2014; Rojas, Bedoya et al., 2015).

\section{Chemical and Mechanical Methods}

Chemical-mechanical methods are the commonest procedures employed for manufacturing nanofibers, with a higher ratio of length to diameter, and smaller diameters compared to those from purely mechanical processes. In this approach, the noncellulosic content is mostly eliminated by alkali treatment or acid 


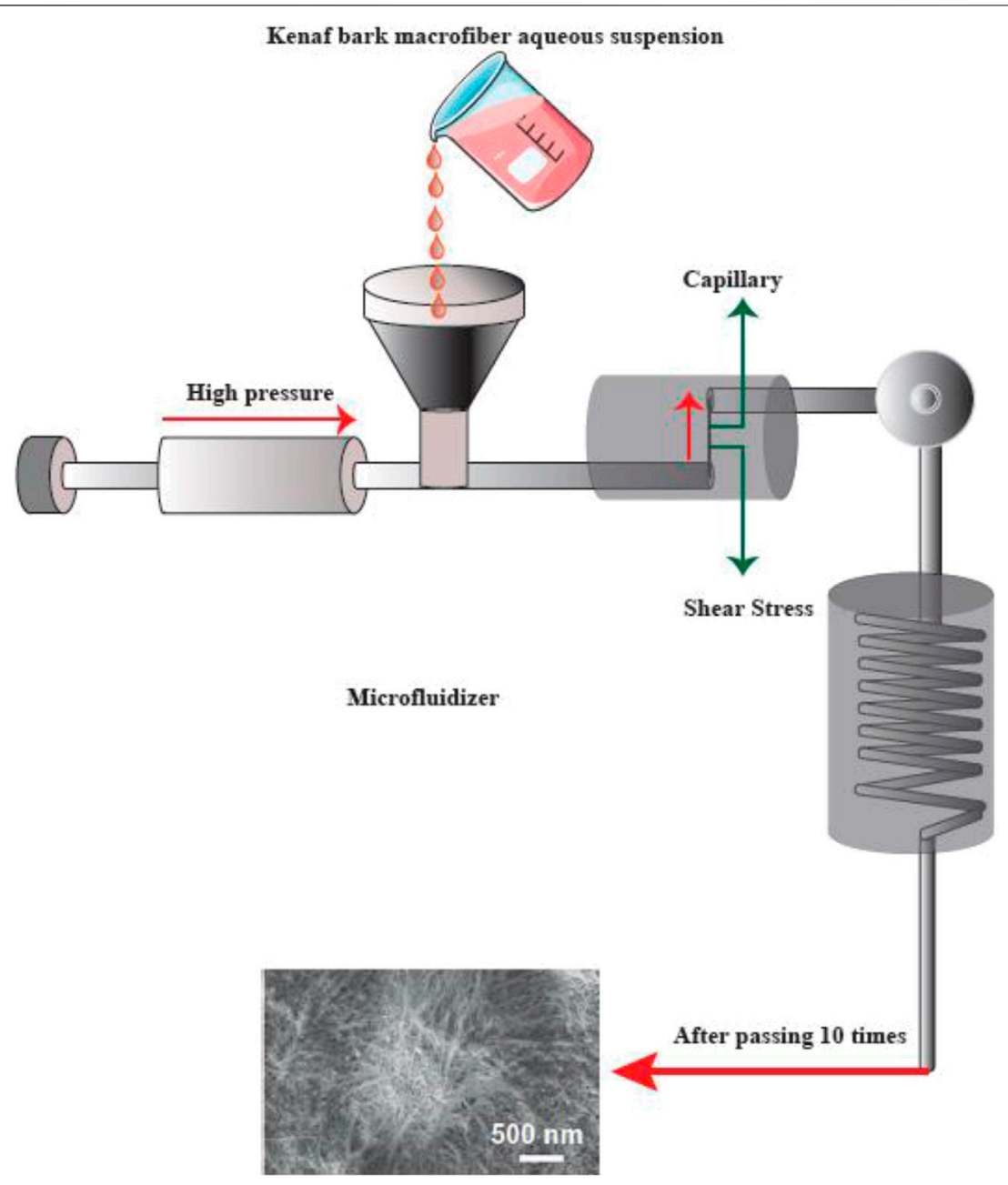

FIGURE 6 | The apparatus for grinding, and SEM images (A) prior to and (B) following the grinding into refined macro-fibers (scale bar: A. 1,000 $\mu$ m and B. $1 \mu \mathrm{m}$ ). This figure adapted from Nishino et al. (Nishino 2017).

hydrolysis. Comparing the disadvantages and advantages of the nanofiber extraction procedures shows that chemomechanical techniques have been the most successful for nanofiber production and purification (Zhang, Elder et al., 2007).

\section{CELLULOSE-BASED NANOFIBRILS AGAINST BACTERIAL INFECTIONS}

Carboxymethyl cellulose (CMC) has become a widely used carbohydrate biopolymer in food packaging and biomedical applications, because of its good film-forming ability, wide availability, non-toxicity, and renewability. CMC films provide a suitable barrier against the environment, with good mechanical properties and transparency. Nevertheless, researchers have investigated many approaches to further improve the mechanical and barrier features, such as blending with other bio-degradable lipids or polymers, and introducing plasticizers, fillers, and cross-linking agents. The use of nanofillers can improve the physical characteristics of the biopolymers, and can also introduce antimicrobial and antioxidant properties to the packaging films (Ahmadi, Ghanbarzadeh et al., 2019). Some of the nanofillers that have been incorporated into biopolymer matrixes are; titanium dioxide $\left(\mathrm{TiO}_{2}\right)$ (Mehrabani et al., 2018a; Karimian et al., 2020), zinc oxide ( $\mathrm{ZnO}$ ) (Oun and Rhim 2017), silicon dioxide $\left(\mathrm{SiO}_{2}\right)$ (Song, Luo et al., 2013), silver (Mehrabani et al., 2018b; Karimian et al., 2020), and copper oxide (Ashjari, Dorraji et al., 2018). Nanoparticles (NPs) composed of chitin have been added to cellulose nanofibers (CNF) and cellulose nanocrystals (CNC) (Lizundia, Fortunati et al., 2016; Tang, Zhang et al., 2018). In recent times bioactive natural compounds have been preferred over synthetic anti-microbial agents or other functional materials to avoid health problems and environmental hazards (Jung and Zhao 2016). For example, Salvadora persica L (Meswak) is a small shrub from the Salvadoraceae family, which is indigenous to the Middle East is found in the south of Iran, Saudi Arabia, Africa, and India (Halawany 2012). Traditionally, Miswak root has been employed as a toothbrush, and was recommended as a "chewing stick" for oral hygiene by the FAO/WHO in 1989. The biological activity of 
S. persica stick extract (SPE) includes antioxidant activity (Mariod, Matthäus et al., 2009), and SPE contains numerous bioactive inorganic and organic compounds, like salvadourea, saponin, salvadorine, vitamin $\mathrm{C}$, amides, cyanates, tannins and alkaloids. Moreover, SPE contains glycosides (salvadoraside and salvadoside), terpenoids, resins, sterols, flavonoids, terpenes, and fatty acids (stearic, oleic, and linoleic acids). Inorganic components include sodium chloride, potassium chloride, calcium, manganese, phosphorus, silica, fluoride, sulfur and magnesium (Al-Sohaibani and Murugan 2012; Farag, Fahmy et al., 2017; Noumi, Snoussi et al., 2017). Researchers have investigated the antimicrobial effects of SPE against Gram-negative and Gram-positive bacteria, including Staphylococcus, Streptococcus, Mycobacteria, Escherichia coli, as well as Candida ssp. a well-known oral yeast (Al-Bayati and Sulaiman 2008; Fallah, Fallah et al., 2015; Al-Ayed, Asaad et al., 2016).

Ahmadi et al. prepared an antimicrobial nanocomposite based on CNF, SPE, and CMC (Ahmadi, Ghanbarzadeh et al., 2019). SEM (scanning electron microscopy) was used to visualize the CNF distribution within the CMC matrix, while EDX (energy dispersive X-ray) spectroscopy showed the presence of minerals and sulfur-containing compounds in the nanocomposite. XRD (X-ray diffraction) and FTIR (Fourier transform infrared) spectroscopy confirmed the presence of SPE and CNF in the nanocomposite structure. Incorporation of $\mathrm{CNF}$ increased the UTS (ultimate tensile strength) while it reduced EB (elongation at breakpoint). However, the addition of 200 or $400 \mathrm{mg} / \mathrm{mL}$ resulted in an EB increase without any decrease in the UTS. TGA (thermal gravimetric analysis) showed that SPE promoted the thermal stability of the nanocomposite. The pure SPE nanocomposites showed good antibacterial activity against both Staphylococcus aureus (Gram-positive) and Escherichia coli (Gram-negative) bacteria. The CMC/CNF-5\%SPE nanocomposite showed improved thermophysical properties and a better UV-barrier function. The encouraging antimicrobial activity against both Gram-positive and Gram-negative bacteria, suggests that adding an extract of $S$. persica to CNF composite films could produce a biologically active food packaging.

Skin wounds are often infection-prone and difficult to treat, and improved wound dressings are urgently required (Balakrishnan, Mohanty et al., 2005). Conventional dressings can be synthetic or natural bandages, cotton wool, or gauze. Saline and gauze help the wound healing in the initial stages due to absorption of exudates and blood, and allow debridement and cleansing. However, these dry dressings do not provide sufficient moisture in the wound environment, and, they tend to become sticky as fluid production decreases. This means they are difficult to remove, resulting in patient discomfort. Due to the lack of occlusion allowing moisture evaporation, gauze dressings also result in a dehydrated wound bed. Therefore, new dressings have been developed to improve upon traditional wound healing treatments. The essential characteristic of modern dressings is the ability to retain and provide enough moisture in the wound environment to facilitate the healing process. Modern dressings are principally categorized based on their materials, including alginates, hydrogels, and hydrocolloids, which can be formed into gels, foam sheets, or thin films (Radhakumary, Antonty et al., 2011). Natural polymers such as glycolipids, polysaccharides, proteoglycans, peptides, and proteins have been widely applied in regenerative medicine. Due to their biodegradability, biocompatibility, and similarity to the extracellular matrix, natural polymers have been applied in wound and burn dressings. Natural polymers help the damaged tissue to repair itself, and result in improved skin regeneration via stimulating cellular healing processes (Mogoșanu and Grumezescu 2014).

Many researchers have attempted to prepare improved and innovative wound dressings. In fact, wound dressings based on hydrogels offer several benefits like a moist environment, a cooling sensation, and allow gaseous exchange, and absorption of the wound exudate (Cheng, Liu et al., 2017; Zhao, Wu et al., 2017). The major cause of wound infections is external contamination by bacterial pathogens, which can not only delay wound healing, but can also invade the host tissue leading to sepsis and possibly to death. Antibiotics and antiseptics are the most often used procedure for prevention of bacterial wound infections. To minimize the of use of broad spectrum antibiotics which can cause antibiotic resistance, researchers have used AgNPs (silver NPs) as local antibacterial agents with less potential to cause resistance and fewer adverse events (Dhand, Soumya et al., 2016). The action mechanism of AgNPs includes causing damage to the bacterial cell membranes, and formation of reactive oxygen species (ROS) (Marambio-Jones and Hoek 2010). However, the toxicity of AgNPs may limit their use, because the particles can penetrate into the tissue and release $\mathrm{Ag}+$ ions. The above problem can be solved by stabilizing the AgNPs by preparing composites with diverse materials (Loo, Fane et al., 2013). The surface of bacterial cellulose was embellished with self-assembled AgNPs to supply anti-bacterial activity (Wu, Zheng et al., 2014). The slower release of silver ions decreased the host cytotoxicity, and decreased bacterial growth over the long term. Bandages constructed from AgNP-decorated nanofibers showed a powerful antibacterial activity against $S$. aureus, and showed lower cytotoxicity against keratinocytes in an ex vivo skin model. Furthermore, antibacterial hydrogels have been prepared using acrylic acid polymers combined with cellulose for full-thickness wound healing. These hydrogels not only killed bacteria, but encouraged cell proliferation and migration (Loh, Mohamad et al., 2018).

Ji Un Shin et al. prepared an antibacterial hydrogel from AgNP-immobilized alginate combined with CNFs obtained from tobacco-based cellulose nanofibers (TCNF) (Shin, Gwon et al., 2018). The CNF surface hydroxyl groups were oxidized to carboxylate groups by reacting with TEMPO $((2,2,6,6-$ tetramethyl piperidine-1-yl) oxidanyl). This was then treated with silver nitrate solution for surface absorption of silver ions. Spectroscopic analysis, XRD, and electron microscopy showed the immobilization of higher quantities of the AgNPs on the TCNF surface compared to the native CNF surface. The AgNP immobilized TCNF was combined with an alginate gel, and the $\mathrm{Ag}$ ions were released gradually from the matrix over 7 days. The alginate gels loaded with AgNPs demonstrated comparable antibacterial activity to alginate gels loaded with 
silver-ions, but showed lower cytotoxicity towards mammalian cells. The anti-bacterial gels could be used on different skin surfaces and wounds to inhibit bacterial growth without harming epidermal cells.

Titanium dioxide $\left(\mathrm{TiO}_{2}\right)$ is a widely studied semi-conducting material used in photonic, optical, energy, and catalysis applications. $\mathrm{TiO}_{2}$ is best known as a photocatalyst, and exists in three different phases; brookite, anatase, and rutile (Gupta, Singh et al., 2013). $\mathrm{TiO}_{2}$ has been shown to possess photoactivated bactericidal properties, especially under blue or UV light. Under ultraviolet irradiation, $\mathrm{TiO}_{2}$ generates many ROS including hydroxl radicals, superoxide, and hydrogen peroxide that disrupt the cell walls of bacteria and inhibit their respiratory system (Mukhopadhyay, Basak et al., 2010; Verdier, Coutand et al., 2014). Nevertheless, because of the fast rate of electron-hole recombination within $\mathrm{TiO}_{2}$, the ROS production is limited (Nino-Martinez, Martinez-Castanon et al., 2008). Furthermore, the immobilization of noble metals (like silver) on the $\mathrm{TiO}_{2}$ surface, slows the recombination of electrons and holes, and therefore increases ROS generation (Seery, George et al., 2007; Liga, Bryant et al., 2011). Antibacterial nanocomposites including $\mathrm{TiO}_{2}$ can prevent bacterial colonization by the release of antibacterial agents, and creation of ROS causing oxidative stress (Wang, Li et al., 2005). A nanocomposite based on cellulose acetate (CA) including $\mathrm{TiO}_{2}$ and AgNPs, showed bactericidal effects based on ROS production (hydrogen peroxide, hydroxyl radicals, singlet oxygen, and superoxide) (Jatoi, Jo et al., 2018).

Jatoi et al. carried out AgNP immobilization on $\mathrm{TiO}_{2}$ nanoparticles using an environmentally green procedure, and combined the $\mathrm{TiO}_{2} / \mathrm{AgNPs}$ into a matrix of CA nanofibers (Kim et al., 2011; Jatoi et al., 2019a). The $\mathrm{TiO}_{2} / \mathrm{AgNP}$ nanocomposite particles were prepared by coating $\mathrm{TiO}_{2}$ nanoparticles with polydopamine hydrochloride followed by a treatment in $\mathrm{AgNO}_{3}$ solution. Subsequently, the $\mathrm{TiO}_{2} / \mathrm{AgNP}$ nanocomposites were added into the $\mathrm{CA}$ solution and electrospun to fabricate $\mathrm{CA} / \mathrm{TiO}_{2} / \mathrm{AgNP}$ composite nanofibers. These samples were characterized using FTIR, XRD, XPS, TEM, SEM, and EDX, and their antibacterial activity investigated. The SEM images showed the regular morphology of the nanofibers, and the antibacterial tests showed significant bacterial killing for $36 \mathrm{~h}$ and significant bacterial growth inhibition for $72 \mathrm{~h}$.

One challenge faced by wound dressings, especially for acute wounds, is the control of bleeding and hemorrhage, that is frequently a cause of trauma death (Gaston, Fraser et al., 2018). Numerous clinical hemostatic formulations have been investigated based on chitosan, thrombin, fibrin, or collagen but they might be difficult to store and use outside a hospital setting. Gelatin is readily available by hydrolysis of collagen, is low cost, and stable in storage, with good hemostatic effects (Lan, Lu et al., 2015; Chen, Guo et al., 2016).

Liu et al. designed a nanocomposite hydrogel with a green color, by combining gelatin (G) with Ag-NH2 NPs (aminated silver NPs) and CNF (Liu, Dai et al., 2018). An IPN (interpenetrating polymeric network) was created by this multi-component interaction, taking the form of a dynamic ionic-bridged (non-covalent) cross-linked hydrogel, CNF/G/
Ag. Moreover, a hydrogel dressing containing Ag-NH2 NPs $(0.5 \mathrm{mg} / \mathrm{mL})$ showed antibacterial activity, self-recovery ability, good mechanical properties, the ability to absorb fluid from the wound bed $(2093.9 \mathrm{~g} / \mathrm{m} 2$ daily), and effective hemostatic performance. More importantly, evaluation of wound healing in vivo and in vitro with $\mathrm{CNF} / \mathrm{G} / \mathrm{Ag}$ demonstrated good biocompatibility ( $100 \%$ viability of infected cells) and wound healing ability ( $83.3 \%$ survival and $~ 90 \%$ healed after 14 days). This hydrogel dressing based on cellulose may be useful for skin wound dressings using green materials.

Hydrogen peroxide $\left(\mathrm{H}_{2} \mathrm{O}_{2}\right)$ is a reactive oxygen species (ROS) formed by oxidoreductase enzymes (lactoperoxidase, glucose oxidase and myeloperoxidase), which is capable of eliminating bacteria by inhibiting protein production, disrupting cell membranes and metabolism, oxidation of thiol groups, and depletion of ROS scavengers. Moreover, $\mathrm{H}_{2} \mathrm{O}_{2}$ can play a role as a substrate for halide or pseudohalide oxidation for the formation of stronger antimicrobial agents (Thallinger et al., 2013). Recently attention has been drawn to laccases, a copper-containing oxidoreductase enzyme found in plants and fungi, due to having no need for cofactors and the broad substrate specificity (Strong and Claus 2011). Laccase enzymes can catalyze reactions with natural polyphenols resulting in the formation of antimicrobial agents, which can kill Gram-negative and Grampositive bacteria (Janusz, Pawlik et al., 2020). Bacterial nanocellulose (BNC) can form a useful ultrafine porous lattice for the immobilization of laccase because of its unique properties, such as high capacity for water absorption, high purity, threedimensional nanostructure, and mechanical strength. The threedimensional porous structure of BNC enables good access of substrates to the active site for continuous operation, easy recovery, and good penetration (Sulaiman, Mokhtar et al., 2015). In a recent study by Sampaio et al., the physical immobilization of a commercial laccase preparation onto BNC was evaluated to assess the antibacterial activity of laccase for wound dressing applications (Sampaio, Padrão et al., 2016). They reported that laccase immobilized onto BNC and formulated as a wound dressing showed satisfactory cytotoxicity for biomedical purposes, with antimicrobial activity against Gram-negative (26\%) and Gram-positive (92\%) bacteria. Depending on the volume of discharge, the dressing should be renewed on average every 1-3 days, and that laccase could act as an effective, non-toxic, inexpensive and durable antimicrobial dressing, even its stability was limited (Sampaio, Padrão et al., 2016).

Naturally occurring polymers such as proteins or polysaccharides are ofen incorporated into antimicrobial products and dressings. Cationic biopolymers alone (e.g. chitosan, CS) or in combination with cellulose, can act as biocides (Kupnik, Primožič et al., 2020). CS is a natural antimicrobial agent derived from chitin by partial deacetylation, and has attracted much attention in commercial fields. When CS is loaded onto nanocellulose (NC), it could enhance the mechanical properties of the NC and also increase the antimicrobial activity of cellulose-based compounds (Boroumand, Badie et al., 2021). CS is a natural polysaccharide containing amino-groups with unique features, 
including intrinsic antibacterial activity, non-toxicity, biocompatibility, and biodegradability (Rashki, Asgarpour et al., 2020). Poonguzhali et al. employed crystalline nanocellulose (CNC) to prepare antimicrobial hybrid structures containing CS. They fabricated CS polyvinylpyrrolidone (PVP)-NC (CPN) bionanocomposites for wound dressing applications (Poonguzhali, Basha et al., 2017). The biocompatible and non-toxic PVP has many applications in wound dressings and also in targeted drug delivery. Polymeric PVP films are effective drug delivery systems, in particular via the buccal and sublingual routes (Poonguzhali, Basha et al., 2017). A modified disk diffusion test was employed to determine the antibacterial activity of CPN against Gram-negative and Gram-positive bacteria. The results showed that the zones of inhibition were larger for $P$. aeruginosa (Gram-negative) compared to $S$. aureus (Gram-positive). The reason for the better inhibition of Gram-negative bacteria was attributed to an interaction between the positive charge of CS and the more negative charge of Gram-negative bacterial cell membrane, resulting in leakage from the bacterial cells and impairment in the microbial metabolism. Moreover, the large surface area of the NC could help the CS to bind to the bacteria, and increase the antimicrobial activity (Kupnik, Primožič et al., 2020).

Chitin, a $\beta-1,4-\mathrm{N}$-acetylglucosamine linear polysaccharide, is part of the cell wall of fungal species, and the exo-skeleton of crustaceans and insects (Szymańska-Chargot, Chylińska et al., 2019). Because of its excellent crystallinity and robust intermolecular bonds, chitin is non-reactive, but has poor water solubility. To improve its solubility, it can undergo partial deacetylation to form chitosan $(\mathrm{CH})$. $\mathrm{CH}$ dissolves in water at lower $\mathrm{pH}$ and has been used to from composites with a broad range of other polymers (Deng, Jung et al., 2017). The principal drawback of chitosan composites is their poor mechanical characteristics (HPS, Abdul Khalil et al., 2016). The positive charge of $\mathrm{CH}$ has led to its use as a natural anti-microbial agent against a variety of microorganisms, with applications in food quality and safety (Kim, Min et al., 2011). Due to its antibacterial activity, biocompatibility, non-toxicity, and biodegradability, $\mathrm{CH}$ has been investigated in the food industry as a thickener and stabilizer, in biomedical engineering, and even in agriculture as a fertilizer (de Alvarenga 2011). The molecular structure of $\mathrm{CH}$ affects its anti-microbial activity, including its degree of polymerization (chain length), and its \% deacetylation. Other important parameters include, the tested microorganisms, the type of medium, the microbial cell age, the chemical composition of the media especially the $\mathrm{pH}$ (Kong, Chen et al., 2010).

Szymańska-Chargot et al. prepared films composed of CCNF (carrot cellulose nanofibrils) combined with CHIT (low-viscosity $\mathrm{CH}$ ) by vacuum filtration (Szymańska-Chargot, Chylińska et al., 2019). The amount of $\mathrm{CH}$ in the films varied between 9 and $33 \%$ of dry weight. The morphology of the film surface was examined by SEM, and they evaluated the $\mathrm{CH}$ distribution within the CCNF matrix. The bonds between CCNF and CHIT were confirmed by FTIR and they found a physical interaction between CHIT and CCNF instead of hydrogen bonding. This result explained the wettability by water. The addition of chitosan to the nanocellulose matrix increased the contact angle of water, so the surface of the composite became more lipophilic. The binding between chitosan and nanocellulose provided an overall denser structure. Analysis of the thermal properties showed better stabilization at high temperatures, with deterioration only occurring at $>300^{\circ} \mathrm{C}$. Moreover, the addition of CHIT to the CCNF matrix reduced the Young's modulus (reduced from $14.71 \mathrm{GPa}$ for CCNF to 8.76 GPa for CCNF/CHIT5). The composite tensile strength (the highest force to a create a fracture) was reduced following the addition of chitosan (from 145.83 MPa for CCNF to $129.43 \mathrm{MPa}$ for CCNF/CHIT5). The composite showed a good inhibitory effect versus S. epidermidis and E. coli. Micrococcus luteus was inhibited at higher concentrations of chitosan in the composites, but Candida krusei and filamentous fungi were not inhibited Table 1 lists some cellulose-based nanofibrils that could be used in composites against bacterial infections.

\section{FUTURE PERSPECTIVES}

One major challenge faced by drug delivery systems is the poor solubility of the drug in water. Thus, to overcome this problem, formulation scientists have been searching for new appropriate excipients. Cellulose nanofibers are such a new excipient, and have only recently been investigated in the pharmaceutical context. The principal characteristics of cellulose nanofibers include lack of toxicity, useful surface chemistry, unique colloidal properties, high surface-area-to-volume, biodegradability, excellent mechanical and rheological properties, and gas barrier properties in the dry state. Recent studies have suggested there are positive molecular interactions between poorly-soluble drugs and cellulose nanofibers. also It has also been shown that in some cases, the interactions between drug molecules and cellulose nanofibers improved the apparent solubility of those drugs. The appropriate cellulose nanofibers can be assembled into a variety of structures, such as capsules, particles, Pickering stabilized lipophilic droplets, films, wet-stable foams, aerogels, and solid materials containing closed cells. These structures can result in tailored sustained release kinetics, and rapid release of poorly soluble drugs (Löbmann and Svagan 2017; Posada, Velásquez-Cock et al., 2020; Pandey 2021). One recent study described cellular solid materials containing closed cells that could be self-assembled using cellulose nanofibers to encapsulate poorly-soluble drugs. Due to their buoyant properties, these foams exhibited prolonged drug release characteristics (hours or even days), and could probably be used as a drug delivery system that could be retained within the stomach for site-specific drug release. However, a rapid release system could also be obtained by formulating aerogels consisting of films or nanoparticles containing poorly-soluble drugs with the appropriate cellulose nanofibers as the matrix material. Moreover, prolonged drug release from films over periods of months could be achieved by choosing different cellulose nanofibers (Moohan, Stewart et al., 2020). Cellulose nanofibers have a unique molecular arrangement that enables the stabilization of oil-droplets in aqueous media (Pickering stabilization). For example, lipid-based droplets could be used 
TABLE 1 | Various cellulose-based nanofibrils used against bacterial infections.

\begin{tabular}{|c|c|c|c|c|c|c|}
\hline $\begin{array}{l}\text { Cellulose nanofibril } \\
\text { composite }\end{array}$ & Form & $\begin{array}{c}\text { Target } \\
\text { microorganisms }\end{array}$ & $\begin{array}{l}\text { Model (In } \\
\text { vitro/In } \\
\text { vivo/ } \\
\text { Human) }\end{array}$ & $\begin{array}{c}\text { Mechanism of } \\
\text { antibacterial activity }\end{array}$ & Finding/application & Ref \\
\hline $\begin{array}{l}\text { Cellulose nanofibrils/PVA } \\
\text { AgNPs }\end{array}$ & Film & Escherichia coli & In vitro & $\begin{array}{l}\mathrm{Ag}+\text { ions release and } \\
\text { permeation of bacterial cell } \\
\text { membranes } \\
\text { AgNPs incorporation into CNF/ } \\
\text { PVA matrix allowed bacterial } \\
\text { growth inhibition }\end{array}$ & $\begin{array}{l}\text { Addition of AgNPs into } \\
\text { CNF/PVA produced a } \\
\text { composite with anti- } \\
\text { microbial activity }\end{array}$ & $\begin{array}{l}\text { Limaye, Gupta et al. } \\
\text { (2019) }\end{array}$ \\
\hline $\begin{array}{l}\text { Carboxymethyl cellulose/ } \\
\text { cellulose nanofibril/ } \\
\text { Salvadora persica. L extract } \\
\text { (CMC/CNF-/SPE) }\end{array}$ & Film & $\begin{array}{l}\text { Staphylococcus } \\
\text { aureus ATCC29213 } \\
\text { E. coli ATCC } 25922\end{array}$ & In vitro & $\begin{array}{l}\text { Cell wall destruction } \\
\text { Change the membrane } \\
\text { permeability Interact with } \\
\text { bacterial outer membrane } \\
\text { Change the membrane potential } \\
\text { and integrity } \\
\text { Change the bacterial water } \\
\text { osmosis gradient }\end{array}$ & $\begin{array}{l}\text { Protects products } \\
\text { from UV } \\
-\end{array}$ & $\begin{array}{l}\text { Ahmadi, Ghanbarzadeh } \\
\text { et al. (2019) }\end{array}$ \\
\hline AgNP@TCNF & Hydrogel & E. coli & In vitro & $\begin{array}{l}\mathrm{Ag}+\text { sustained release for a } \\
\text { prolonged period } \\
\text { Medium from hydrogel } \\
\text { incubation decreased bacterial } \\
\text { growth with no cytotoxicity }\end{array}$ & $\begin{array}{l}\text { Wound dressing } \\
\text { Prolonged antibacterial } \\
\text { activity }\end{array}$ & Shin, Gwon et al. (2018) \\
\hline $\begin{array}{l}\text { Poly (عCaprolactone)/ } \\
\text { Cellulose Nanofiber/ZrO2 }\end{array}$ & Film & $\begin{array}{l}\text { S. aureus } \\
\text { E. coli } \\
\text { Candida albicans }\end{array}$ & In-vitro & $\begin{array}{l}\text { Antifungal and anti-bacterial } \\
\text { activity due to } \mathrm{nZrO} 2 \text { in the } \\
\text { composite } \\
\text { Good antibacterial activity } \\
\text { - }\end{array}$ & Wound dressing & $\begin{array}{l}\text { Karimian, Mehrabani et al. } \\
(2020)\end{array}$ \\
\hline $\begin{array}{l}\text { Cellulose/TiO2/Ag } \\
\text { nanofibers }\end{array}$ & - & $\begin{array}{l}\text { E. coli } \\
\text { S. aureus }\end{array}$ & In vitro & - & $\begin{array}{l}\text { Applicable in bone tissue } \\
\text { regeneration } \\
\text { Wound-healing } \\
\text { applications }\end{array}$ & Ashraf, Sofi et al. (2020) \\
\hline $\begin{array}{l}\text { Cellulose nanofibrils/ } / \mathrm{TiO}_{2} / \\
\text { antibiotics } \\
\text { Cellulose nanofibrils/TiO2/ } \\
\text { Phos } \\
- \\
\text { - }\end{array}$ & - & $\begin{array}{l}\text { S. aureus NBRC } \\
100910 \\
\text { E. coli NCTC9001 }\end{array}$ & In vitro & $\begin{array}{l}- \\
-\end{array}$ & $\begin{array}{l}\text { Potentially useful as } \\
\text { antimicrobial patches } \\
\text { Long-term release of } \\
\text { antibiotics } \\
\text { Prolonged action to } \\
\text { prevent bacterial growth } \\
\text { Application as } \\
\text { disinfectants }\end{array}$ & $\begin{array}{l}\text { Galkina, Önneby et al. } \\
\text { (2015) }\end{array}$ \\
\hline AgNP/cellulose nanofibers & - & $\begin{array}{l}\text { E. coli } \\
\text { S. aureus } \\
-\end{array}$ & In vitro & $\begin{array}{l}\text { AgNPs provide slow release of } \\
\mathrm{Ag}+\text { ions } \\
\text { Complete inhibition of bacterial } \\
\text { growth } \\
\mathrm{Ag}+\text { ions inhibit ATP production, } \\
\text { DNA synthesis, and inhibit } \\
\text { respiratory system, causing } \\
\text { bacterial killing }\end{array}$ & $\begin{array}{l}\text { Biocomposite for } \\
\text { antibacterial applications }\end{array}$ & Jatoi et al. (2019a) \\
\hline $\begin{array}{l}\text { Cellulose acetate }(\mathrm{CA}) / \mathrm{TiO} 2 / \\
\text { AgNP }\end{array}$ & - & $\begin{array}{l}\text { E. coli } \\
\text { S. aureus } \\
-\end{array}$ & In vitro & $\begin{array}{l}\text { Disruption of bacterial cell walls } \\
\text { Inhibition of DNA synthesis and } \\
\text { respiratory systems } \\
\text { ROS (reactive oxygen species) } \\
\text { generation }\end{array}$ & $\begin{array}{l}\text { Nano-composite for } \\
\text { prolonged anti-bacterial } \\
\text { applications }\end{array}$ & $\begin{array}{l}\text { Jatoi et al. (2019b), Kim } \\
\text { et al. (2011) }\end{array}$ \\
\hline $\begin{array}{l}\text { CAVcarbon nanotube (CNT)/ } \\
\text { AgNP nanofibers }\end{array}$ & - & $\begin{array}{l}\text { E. coli } \\
\text { S. aureus } \\
- \\
-\end{array}$ & In vitro & $\begin{array}{l}\text { ROS generation } \\
\text { Disruption of bacterial cell walls } \\
\text { Damage to DNA } \\
\text { Inhibition of bacterial growth }\end{array}$ & $\begin{array}{l}\text { Long term antibacterial } \\
\text { applications }\end{array}$ & $\begin{array}{l}\text { Jatoi, Ogasawara et al. } \\
(2020)\end{array}$ \\
\hline Cellulose nanofibrils/G/Ag & Hydrogel & $\begin{array}{l}\text { S. aureus } \\
\text { Pseudomonas } \\
\text { aeruginosa }\end{array}$ & $\begin{array}{l}\text { In vitro } \\
\text { In vivo }\end{array}$ & - & Wound dressing & Liu, Dai et al. (2018) \\
\hline $\begin{array}{l}\mathrm{Cu} @ \mathrm{SiO} 2 / \text { bacterial cellulose } \\
\text { nanofibers }\end{array}$ & Film & $\begin{array}{l}\text { S. aureus } \\
\text { Escherichia coli }\end{array}$ & In vitro & $\begin{array}{l}\text { Bacterial inactivation } \\
\text { Interaction with microbial DNA } \\
\text { inhibits replication }\end{array}$ & $\begin{array}{l}\text { Suitable for biomedical } \\
\text { applications } \\
\text { Prolonged antimicrobial } \\
\text { activity }\end{array}$ & Ma, Huang et al. (2016) \\
\hline
\end{tabular}

(Continued on following page) 
TABLE 1 | (Continued) Various cellulose-based nanofibrils used against bacterial infections.

\begin{tabular}{|c|c|c|c|c|c|c|}
\hline $\begin{array}{l}\text { Cellulose nanofibril } \\
\text { composite }\end{array}$ & Form & $\begin{array}{c}\text { Target } \\
\text { microorganisms }\end{array}$ & $\begin{array}{l}\text { Model (In } \\
\text { vitro/In } \\
\text { vivo/ } \\
\text { Human) }\end{array}$ & $\begin{array}{c}\text { Mechanism of } \\
\text { antibacterial activity }\end{array}$ & Finding/application & Ref \\
\hline & & $\begin{array}{l}- \\
- \\
- \\
-\end{array}$ & & $\begin{array}{l}\text { Destruction of sulfhydryl groups } \\
\text { in the metabolic enzymes in the } \\
\text { electron transfer chain } \\
\text { Binds to bacterial cell walls } \\
\text { Enhance membrane permeability } \\
\text { Denature protein structure } \\
\text { Change enzyme activity } \\
\text { Cell death }\end{array}$ & $\begin{array}{l}- \\
- \\
- \\
-\end{array}$ & \\
\hline $\begin{array}{l}\text { AgNPs/cellulose nanofiber } \\
\text { (AgNP/CNF) }\end{array}$ & Aerogel & $\begin{array}{l}\text { E. coli } \\
\text { Aspergillus niger } \\
- \\
- \\
- \\
- \\
-\end{array}$ & In vitro & $\begin{array}{l}\text { Release of Ag ions } \\
\text { Oxidation of the AgNPs surface } \\
\text { in contact with media } \\
\text { Ag species bind to microbial } \\
\text { membrane increasing } \\
\text { permeability } \\
\text { Inhibit replication and respiration } \\
\text { High surface area of CNF aerogel } \\
\text { Acts as a sponge to enhance } \\
\text { antifungal and antibacterial } \\
\text { activity } \\
\text { CNFs act as a sponge-like } \\
\text { support for AgNPs }\end{array}$ & $\begin{array}{l}\text { Increased antifungal and } \\
\text { antibacterial activity }\end{array}$ & $\begin{array}{l}\text { (Matsuyama, Morotomi } \\
\text { et al. 2019) }\end{array}$ \\
\hline $\begin{array}{l}\text { EMPO-oxidized cellulose } \\
\text { nanofibers (TOCNF)/PLA } \\
\text { TiO2 }\end{array}$ & Film & $\begin{array}{l}\text { Bacillus subtilis } \\
\text { P. aeruginosa } \\
\text { E. coli } \\
\text { S. aureus }\end{array}$ & In vitro & $\begin{array}{l}\text { Addition of TiO2 to } \\
\text { nanocomposite films improved } \\
\text { antibacterial activity against } \\
\text { Gram-positive and Gram- } \\
\text { negative bacteria }\end{array}$ & $\begin{array}{l}\text { Use as a packaging } \\
\text { material } \\
\text { Increased antibacterial } \\
\text { effects } \\
- \\
-\end{array}$ & $\begin{array}{l}\text { El-Gendy, Abou-Zeid } \\
\text { et al. (2017) }\end{array}$ \\
\hline $\begin{array}{l}\text { Carrot cellulose nanofibrils } \\
\text { (CCNF)/chitosan }\end{array}$ & Film & $\begin{array}{l}\text { S. epidermidis } \\
\text { E. coli } \\
\text { B. cereus } \\
\text { Micrococcus luteus } \\
\text { Candida krusei }\end{array}$ & In vitro & - & $\begin{array}{l}\text { CCNF composite plus } \\
\text { chitosan showed } \\
\text { antimicrobial activity } \\
\text { Bacteriostatic and } \\
\text { fungistatic } \\
\text { - } \\
\text { - } \\
\text { - }\end{array}$ & $\begin{array}{l}\text { Szymańska-Chargot, } \\
\text { Chylińska et al. (2019) }\end{array}$ \\
\hline $\begin{array}{l}\mathrm{Cu} / \text { cellulose nanofibrils } \\
\mathrm{Ag} / \text { cellulose nanofibrils }\end{array}$ & - & $\begin{array}{l}\text { E. coli } \\
\text { B. subtilis }\end{array}$ & In vitro & $\begin{array}{l}\text { Antibacterial activity was } \\
\text { proportional to the release of } \\
\text { copper or silver ions }\end{array}$ & $\begin{array}{l}\text { Composite metal/ } \\
\text { cellulose nanofibers } \\
\text { showed high antibacterial } \\
\text { activity }\end{array}$ & $\begin{array}{l}\text { Phan, Dorjjugder et al. } \\
\text { (2019) }\end{array}$ \\
\hline $\begin{array}{l}\text { Cellulose nanofibers/ } \\
\text { polylactic acid/ethanolic } \\
\text { extract of propolis (CNFs/ } \\
\text { PLA/EEP) }\end{array}$ & Film & $\begin{array}{l}\text { S. aureus } \\
\text { B. anthracis } \\
\text { C. albicans } \\
\text { B. cereus } \\
\text { S. enterica } \\
\text { E. coli }\end{array}$ & In vitro & $\begin{array}{l}\text { Propolis acts via inhibiting } \\
\text { replication of DNA and cell } \\
\text { division }\end{array}$ & $\begin{array}{l}\text { Higher antibacterial } \\
\text { efficacy against Gram- } \\
\text { positive bacteria }\end{array}$ & $\begin{array}{l}\text { Abdulkhani, } \\
\text { Hosseinzadeh et al. } \\
(2017)\end{array}$ \\
\hline
\end{tabular}

for delivery of poorly soluble drugs. Cellulose nanofibers are truly versatile excipients with regard to the regulation of drug release kinetics (Löbmann and Svagan 2017). Nevertheless, more research is needed to fully understand their interactions and establish their role in the delivery of poorly-soluble drugs both in vitro and in vivo in disease models.

Cellulose nanofibrils are frequently used in the formulation of antimicrobial materials, such as antibacterial hydrogels, wrapping papers, and thin films. These products can be used as drug carriers, food packaging films, infected wound-healing dressings, and multifunctional antibacterial films. Nevertheless, since the cellulose nanofibrils have little intrinsic antimicrobial activity, their application has been limited in biomedical applications. Hence, different technologies are used to improve the antibacterial properties of cellulose nanofibril-based materials, including antibiotic addition, surface modification, combining with nanomaterials, or antibacterial polymers. Various modifications have led to improvements in the physicochemical features of materials, particularly at the nanoscale (Li, Cha et al., 2018; Bagde and Nadanathangam 2019; Han, Wang et al., 2019; Wang, Yin et al., 2020). However, how the incorporation of exogenous molecules affects the biocompatibility and/or cytotoxicity of the cellulose nanofibrils should be addressed in future studies. Despite some 
remarkable advances having been made in biomedical cellulose nanofibrils, this field is still in its infancy.

\section{CONCLUSION}

Since nanocellulose does not have any antimicrobial activity on its own, its use as antimicrobial wound dressings is limited. Therefore, anti-microbial biomaterials based on nanocellulose are commonly prepared by combining nanocellulose with other antimicrobial agents (frequently using silver) using either chemical or physical approaches. The antibacterial assays have confirmed the efficient antibacterial activity of several nanocellulose-based antimicrobial biomaterials. Modified cellulose-based nanofibrils have been effective to inhibit bacterial growth (in both liquid medium and agar plates), and can kill several logs of microbial cells. Moreover, evaluation of wound healing in vivo and in vitro has shown that nanocellulose-

\section{REFERENCES}

Abdul Khalil, H. P. S., Saurabh, C. K., A.S., A., Nurul Fazita, M. R., Syakir, M. I., Davoudpour, Y., et al. (2016). A Review on Chitosan-Cellulose Blends and Nanocellulose Reinforced Chitosan Biocomposites: Properties and Their Applications. Carbohydr. Polym. 150, 216-226. doi:10.1016/ j.carbpol.2016.05.028

Abdul Khalil, H. P. S., Davoudpour, Y., Islam, M. N., Mustapha, A., Sudesh, K., Dungani, R., et al. (2014). Production and Modification of Nanofibrillated Cellulose Using Various Mechanical Processes: a Review. Carbohydr. Polym. 99, 649-665. doi:10.1016/j.carbpol.2013.08.069

Abdulkhani, A., Hosseinzadeh, J., Ashori, A., and Esmaeeli, H. (2017). Evaluation of the Antibacterial Activity of Cellulose Nanofibers/polylactic Acid Composites Coated with Ethanolic Extract of Propolis. Polym. Compos. 38 (1), 13-19. doi:10.1002/pc.23554

Abe, K., Iwamoto, S., and Yano, H. (2007). Obtaining Cellulose Nanofibers with a Uniform Width of $15 \mathrm{Nm}$ from wood. Biomacromolecules 8 (10), 3276-3278. doi:10.1021/bm700624p

Ahmadi, R., Ghanbarzadeh, B., Ayaseh, A., Kafil, H. S., Özyurt, H., Katourani, A., et al. (2019). The Antimicrobial Bio-Nanocomposite Containing Nonhydrolyzed Cellulose Nanofiber (CNF) and Miswak (Salvadora Persica L.) Extract. Carbohydr. Polym. 214, 15-25. doi:10.1016/j.carbpol.2019.03.010

Al-Ayed, M. S. Z., Asaad, A. M., Qureshi, M. A., Attia, H. G., and AlMarrani, A. H. (2016). Antibacterial Activity of Salvadora Persica L.(Miswak) Extracts against Multidrug Resistant Bacterial Clinical Isolates, Evid. Based Complement Alternat. Med. 2016 (6), 1-5. doi:10.1155/2016/7083964

Al-Bayati, F. A., and Sulaiman, K. D. (2008). In Vitro antimicrobial Activity of Salvadora Persica L. Extracts against Some Isolated Oral Pathogens in Iraq. Turkish J. Biol. 32 (1), 57-62.

Al-Sohaibani, S., and Murugan, K. (2012). Anti-biofilm Activity ofSalvadora Persicaon Cariogenic Isolates ofStreptococcus Mutans:in Vitroand Molecular Docking Studies. Biofouling 28 (1), 29-38. doi:10.1080/08927014.2011.647308

Alavi, M., and Kennedy, J. F. (2021). Recent Advances of Fabricated and Modified $\mathrm{Ag}, \mathrm{Cu}, \mathrm{CuO}$ and $\mathrm{ZnO}$ Nanoparticles by Herbal Secondary Metabolites, Cellulose and Pectin Polymers for Antimicrobial Applications. Cellulose 28, 1-14. doi:10.1007/s10570-021-03746-5

Anirudhan, T. S., and Deepa, J. R. (2017). Nano-zinc Oxide Incorporated Graphene Oxide/nanocellulose Composite for the Adsorption and Photo Catalytic Degradation of Ciprofloxacin Hydrochloride from Aqueous Solutions. J. Colloid Interf. Sci. 490, 343-356. doi:10.1016/j.jcis.2016.11.042

Ashjari, H. R., Dorraji, M. S. S., Fakhrzadeh, V., Eslami, H., Rasoulifard, M. H., Rastgouy-Houjaghan, M., et al. (2018). Starch-based polyurethane/CuO Nanocomposite Foam: Antibacterial Effects for Infection Control. Int. J. Biol. macromolecules 111, 1076-1082. doi:10.1016/j.ijbiomac.2018.01.137 based antimicrobial hydrogel dressings possess good biocompatibility, remarkable antibacterial efficacy, and can hasten the time course of wound healing. Cellulose-based nanofibrils can act as a bio-composite for antibacterial applications, as well as drug carriers, packaging materials, and wound dressing materials. This approach using cellulose-based nanocomposite hydrogels with multi-component construction could provide innovative wound dressings with long-lasting antimicrobial activity.

\section{AUTHOR CONTRIBUTIONS}

HM and MRH contributed in conception, design, statistical analysis and drafting of the manuscript. SR, NS, ZY, MR, MH, EM, FA, FA, RSL, and SM contributed in data collection and manuscript drafting. All authors approved the final version for submission.

Ashraf, R., Sofi, H. S., Akram, T., Rather, H. A., Abdal-hay, A., Shabir, N., et al. (2020). Fabrication of Multifunctional cellulose/TiO2/Ag Composite Nanofibers Scaffold with Antibacterial and Bioactivity Properties for Future Tissue Engineering Applications. J. Biomed. Mater. Res. 108 (4), 947-962. doi:10.1002/jbm.a.36872

Bagde, P., and Nadanathangam, V. (2019). Mechanical, Antibacterial and Biodegradable Properties of Starch Film Containing Bacteriocin Immobilized Crystalline Nanocellulose. Carbohydr. Polym. 222, 115021. doi:10.1016/j.carbpol.2019.115021

Balakrishnan, B., Mohanty, M., Umashankar, P., and Jayakrishnan, A. (2005). Evaluation of an In Situ Forming Hydrogel Wound Dressing Based on Oxidized Alginate and Gelatin. Biomaterials 26 (32), 6335-6342. doi:10.1016/ j.biomaterials.2005.04.012

Boroumand, H., Badie, F., Mazaheri, S., Seyedi, Z. S., Nahand, J. S., Nejati, M., et al. (2021). Chitosan-Based Nanoparticles against Viral Infections. Front. Cell Infect. Microbiol. 11, 175. doi:10.3389/fcimb.2021.643953

Chen, H., Guo, L., Wicks, J., Ling, C., Zhao, X., Yan, Y., et al. (2016). Quickly Promoting Angiogenesis by Using a DFO-Loaded Photo-Crosslinked Gelatin Hydrogel for Diabetic Skin Regeneration. J. Mater. Chem. B 4 (21), 3770-3781. doi:10.1039/c6tb00065g

Cheng, F., Liu, C., Wei, X., Yan, T., Li, H., He, J., et al. (2017). Preparation and Characterization of 2,2,6,6-Tetramethylpiperidine-1-Oxyl (TEMPO)-Oxidized Cellulose Nanocrystal/Alginate Biodegradable Composite Dressing for Hemostasis Applications. ACS Sust. Chem. Eng. 5 (5), 3819-3828. doi:10.1021/acssuschemeng.6b02849

Council, N. R. (2006). Treating Infectious Diseases in a Microbial World: Report of Two Workshops on Novel Antimicrobial Therapeutics.

de Alvarenga, E. S. (2011). Characterization and Properties of Chitosan. Biotechnol. biopolymers 91, 48-53. doi:10.5772/17020

Deng, Z., Jung, J., and Zhao, Y. (2017). Development, Characterization, and Validation of Chitosan Adsorbed Cellulose Nanofiber (CNF) Films as Water Resistant and Antibacterial Food Contact Packaging. LWT - Food Sci. Tech. 83, 132-140. doi:10.1016/j.lwt.2017.05.013

Dhand, V., Soumya, L., Bharadwaj, S., Chakra, S., Bhatt, D., and Sreedhar, B. (2016). Green Synthesis of Silver Nanoparticles Using Coffea Arabica Seed Extract and its Antibacterial Activity. Mater. Sci. Eng. C 58, 36-43. doi:10.1016/ j.msec.2015.08.018

Dufresne, A. (2013). Nanocellulose: a New Ageless Bionanomaterial. Mater. Today 16 (6), 220-227. doi:10.1016/j.mattod.2013.06.004

El-Gendy, A., Abou-Zeid, R. E., Salama, A., Diab, M. A.-H. A.-R., and El-Sakhawy, M. (2017). TEMPO-oxidized Cellulose Nanofibers/polylactic acid/TiO2 as Antibacterial Bionanocomposite for Active Packaging. Egypt. J. Chem. 60 (6), 1007-1014. doi:10.21608/ejchem.2017.1835.1153

Fallah, M., Fallah, F., Kamalinejad, M., Malekan, M. A., Akhlaghi, Z., and Esmaeili, M. (2015). The Antimicrobial Effect of Aquatic Extract of Salvadora Persica on 
Mycobacterium Bovis In Vitro. Int. J. Mycobacteriology 4, 167-168. doi:10.1016/j.ijmyco.2014.10.043

Farag, M. A., Fahmy, S., Choucry, M. A., Wahdan, M. O., and Elsebai, M. F. (2017). Metabolites Profiling Reveals for Antimicrobial Compositional Differences and Action Mechanism in the Toothbrushing Stick "Miswak" Salvadora Persica. J. Pharm. Biomed. Anal. 133, 32-40. doi:10.1016/j.jpba.2016.11.018

Galkina, O. L., Önneby, K., Huang, P., Ivanov, V. K., Agafonov, A. V., Seisenbaeva, G. A., et al. (2015). Antibacterial and Photochemical Properties of Cellulose Nanofiber-Titania Nanocomposites Loaded with Two Different Types of Antibiotic Medicines. J. Mater. Chem. B 3 (35), 7125-7134. doi:10.1039/ c5tb01382h

Gaston, E., Fraser, J. F., Xu, Z. P., and Ta, H. T. (2018). Nano- and Micro-materials in the Treatment of Internal Bleeding and Uncontrolled Hemorrhage. Nanomedicine: Nanotechnology, Biol. Med. 14 (2), 507-519. doi:10.1016/ j.nano.2017.11.007

Gupta, K., Singh, R. P., Pandey, A., and Pandey, A. (2013). Photocatalytic Antibacterial Performance of $\mathrm{TiO} 2$ and $\mathrm{Ag}$-Doped $\mathrm{TiO} 2$ against S. aureus. P. aeruginosa and E. coli. Beilstein J. Nanotechnol. 4 (1), 345-351. doi:10.3762/ bjnano.4.40

Halawany, H. S. (2012). A Review on Miswak (Salvadora Persica) and its Effect on Various Aspects of Oral Health. Saudi Dental J. 24 (2), 63-69. doi:10.1016/ j.sdentj.2011.12.004

Han, J., Wang, S., Zhu, S., Huang, C., Yue, Y., Mei, C., et al. (2019). Electrospun Core-Shell Nanofibrous Membranes with Nanocellulose-Stabilized Carbon Nanotubes for Use as High-Performance Flexible Supercapacitor Electrodes with Enhanced Water Resistance, Thermal Stability, and Mechanical Toughness. ACS Appl. Mater. Inter. 11 (47), 44624-44635. doi:10.1021/ acsami.9b16458

Hassan, G., Forsman, N., Wan, X., Keurulainen, L., Bimbo, L. M., Stehl, S., et al. (2020). Non-leaching, Highly Biocompatible Nanocellulose Surfaces that Efficiently Resist Fouling by Bacteria in an Artificial Dermis Model. ACS Appl. Bio Mater. 3 (7), 4095-4108. doi:10.1021/acsabm.0c00203

Hayashi, N., and Kondo, T. (2015). "Enzymatically Produced Nano-Ordered Elements Containing Cellulose I $\beta$ Crystalline Domains of Cladophora Cellulose," in Handbook of Polymer Nanocomposites. Processing, Performance and Application (Springer), 1-14. doi:10.1007/978-3-64245232-1_58

Hubbe, M. A., Rojas, O. J., Lucia, L. A., and Sain, M. (2008). Cellulosic Nanocomposites. A Review. BioRes 3 (3), 929-980. doi:10.15376/ biores.3.3.929-980

Iwamoto, S., Kai, W., Isogai, T., Saito, T., Isogai, A., and Iwata, T. (2010). Comparison Study of TEMPO-Analogous Compounds on Oxidation Efficiency of wood Cellulose for Preparation of Cellulose Nanofibrils. Polym. Degrad. Stab. 95 (8), 1394-1398. doi:10.1016/j.polymdegradstab.2010.01.017

Janusz, G., Pawlik, A., Świderska-Burek, U., Polak, J., Sulej, J., Jarosz-Wilkołazka, A., et al. (2020). Laccase Properties, Physiological Functions, and Evolution. Ijms 21 (3), 966. doi:10.3390/ijms21030966

Jatoi, A. W., Jo, Y. K., Lee, H., Oh, S. G., Hwang, D. S., Khatri, Z., et al. (2018). Antibacterial Efficacy of Poly(vinyl Alcohol) Composite Nanofibers Embedded with Silver-anchored Silica Nanoparticles. J. Biomed. Mater. Res. 106 (3), 1121-1128. doi:10.1002/jbm.b.33925

Jatoi, A. W., Kim, I. S., and Ni, Q.-Q. (2019b). Cellulose Acetate Nanofibers Embedded with AgNPs Anchored TiO2 Nanoparticles for Long Term Excellent Antibacterial Applications. Carbohydr. Polym. 207, 640-649. doi:10.1016/ j.carbpol.2018.12.029

Jatoi, A. W., Ogasawara, H., Kim, I. S., and Ni, Q.-Q. (2020). Cellulose Acetate/ multi-wall Carbon nanotube/Ag Nanofiber Composite for Antibacterial Applications. Mater. Sci. Eng. C 110, 110679. doi:10.1016/j.msec.2020.110679

Jatoi, A. W., Ogasawara, H., Kim, I. S., and Ni, Q.-Q. (2019a). Dopa-based Facile Procedure to Synthesize AgNP/cellulose Nanofiber Composite for Antibacterial Applications. Appl. Nanosci 9 (8), 1661-1670. doi:10.1007/s13204-019-00952-3

Jiang, Z., Qiao, M., Ren, X., Zhu, P., and Huang, T. S. (2017). Preparation of Antibacterial Cellulose with S-triazine-based Quaternarized N-halamine. J. Appl. Polym. Sci. 134 (26). doi:10.1002/app.44998

Jung, J., and Zhao, Y. (2016). "Antimicrobial Packaging for Fresh and Minimally Processed Fruits and Vegetables," in Antimicrobial Packaging for Fresh and Minimally Processed Fruits and Vegetables. Antimicrobial Food Packaging (Elsevier), 243-256. doi:10.1016/b978-0-12-800723-5.00018-8
Kafy, A., Kim, H. C., Zhai, L., Kim, J. W., Kang, L. V. T. J., and Kim, J. (2017). Cellulose Long Fibers Fabricated from Cellulose Nanofibers and its strong and Tough Characteristics. Sci. Rep. 7 (1), 17683-17688. doi:10.1038/s41598-01717713-3

Kalia, S., Dufresne, A., Cherian, B. M., Kaith, B. S., Avérous, L., Njuguna, J., et al. (2011). Cellulose-based Bio-And Nanocomposites: A Review. International journal of polymer science 2011. doi:10.1155/2011/837875

Karimian, R., Mehrabani, M. G., Mehramuz, B., Ganbarov, K., Ejlali, L., Tanomand, A., et al. (2020). Poly ( $\varepsilon$-Caprolactone)/Cellulose Nanofiber Blend Nanocomposites Containing $\mathrm{ZrO} 2$ Nanoparticles: A New Biocompatible Wound Dressing Bandage with Antimicrobial Activity. Adv. Pharm. Bull. 10 (4), 577-585.

Kim, C. H., Choi, J. W., Chun, H. J., and Choi, K. S. (1997). Synthesis of Chitosan Derivatives with Quaternary Ammonium Salt and Their Antibacterial Activity. Polym. Bull. 38 (4), 387-393. doi:10.1007/s002890050064

Kim, K. W., Min, B. J., Kim, Y.-T., Kimmel, R. M., Cooksey, K., and Park, S. I. (2011). Antimicrobial Activity against Foodborne Pathogens of Chitosan Biopolymer Films of Different Molecular Weights. LWT - Food Sci. Tech. 44 (2), 565-569. doi:10.1016/j.lwt.2010.08.001

Kocer, H. B., Akdag, A., Ren, X., Broughton, R. M., Worley, S. D., and Huang, T. S. (2008). Effect of Alkyl Derivatization on Several Properties of N-Halamine Antimicrobial Siloxane Coatings. Ind. Eng. Chem. Res. 47 (20), 7558-7563. doi:10.1021/ie800899u

Kong, M., Chen, X. G., Xing, K., and Park, H. J. (2010). Antimicrobial Properties of Chitosan and Mode of Action: a State of the Art Review. Int. J. Food Microbiol. 144 (1), 51-63. doi:10.1016/j.ijfoodmicro.2010.09.012

Kupnik, K., Primožič, M., Kokol, V., and Leitgeb, M. (2020). Nanocellulose in Drug Delivery and Antimicrobially Active Materials. Polymers 12 (12), 2825. doi: $10.3390 /$ polym 12122825

Lan, G., Lu, B., Wang, T., Wang, L., Chen, J., Yu, K., et al. (2015). Chitosan/gelatin Composite Sponge Is an Absorbable Surgical Hemostatic Agent. Colloids Surf. B: Biointerfaces 136, 1026-1034. doi:10.1016/j.colsurfb.2015.10.039

Lavoine, N., Desloges, I., Dufresne, A., and Bras, J. (2012). Microfibrillated Cellulose - its Barrier Properties and Applications in Cellulosic Materials: A Review. Carbohydr. Polym. 90 (2), 735-764. doi:10.1016/j.carbpol.2012.05.026

Li, J., Cha, R., Mou, K., Zhao, X., Long, K., Luo, H., et al. (2018). NanocelluloseBased Antibacterial Materials. Adv. Healthc. Mater. 7 (20), 1800334. doi:10.1002/adhm.201800334

Liga, M. V., Bryant, E. L., Colvin, V. L., and Li, Q. (2011). Virus Inactivation by Silver Doped Titanium Dioxide Nanoparticles for Drinking Water Treatment. Water Res. 45 (2), 535-544. doi:10.1016/j.watres.2010.09.012

Limaye, M. V., Gupta, V., Singh, S. B., Paik, G. R., and Singh, P. (2019). Antimicrobial Activity of Composite Consisting of Cellulose Nanofibers and Silver Nanoparticles. ChemistrySelect 4 (41), 12164-12169. doi:10.1002/ slct. 201901572

Lin, N., and Dufresne, A. (2014). Nanocellulose in Biomedicine: Current Status and Future prospect. Eur. Polym. J. 59, 302-325. doi:10.1016/ j.eurpolymj.2014.07.025

Liu, R., Dai, L., Si, C., and Zeng, Z. (2018). Antibacterial and Hemostatic Hydrogel via Nanocomposite from Cellulose Nanofibers. Carbohydr. Polym. 195, 63-70. doi:10.1016/j.carbpol.2018.04.085

Lizundia, E., Fortunati, E., Dominici, F., Vilas, J. L., León, L. M., Armentano, I., et al. (2016). PLLA-grafted Cellulose Nanocrystals: Role of the CNC Content and Grafting on the PLA Bionanocomposite Film Properties. Carbohydr. Polym. 142, 105-113. doi:10.1016/j.carbpol.2016.01.041

Löbmann, K., and Svagan, A. J. (2017). Cellulose Nanofibers as Excipient for the Delivery of Poorly Soluble Drugs. Int. J. pharmaceutics 533 (1), 285-297. doi:10.1016/j.ijpharm.2017.09.064

Loh, E. Y. X., Mohamad, N., Fauzi, M. B., Ng, M. H., Ng, S. F., and Mohd Amin, M. C. I. (2018). Development of a Bacterial Cellulose-Based Hydrogel Cell Carrier Containing Keratinocytes and Fibroblasts for Full-Thickness Wound Healing. Sci. Rep. 8 (1), 2875-2912. doi:10.1038/s41598-018-21174-7

Loo, S.-L., Fane, A. G., Lim, T.-T., Krantz, W. B., Liang, Y.-N., Liu, X., et al. (2013). Superabsorbent Cryogels Decorated with Silver Nanoparticles as a Novel Water Technology for point-of-use Disinfection. Environ. Sci. Technol. 47 (16), 9363-9371. doi:10.1021/es401219s

Lungu, M.-V., Vasile, E., Lucaci, M., Pătroi, D., Mihăilescu, N., Grigore, F., et al. (2016). Investigation of Optical, Structural, Morphological and Antimicrobial 
Properties of Carboxymethyl Cellulose Capped Ag-ZnO Nanocomposites Prepared by Chemical and Mechanical Methods. Mater. Characterization 120, 69-81. doi:10.1016/j.matchar.2016.08.022

Ma, B., Huang, Y., Zhu, C., Chen, C., Chen, X., Fan, M., et al. (2016). Novel Cu@ $\mathrm{SiO} /$ /bacterial Cellulose Nanofibers: Preparation and Excellent Performance in Antibacterial Activity. Mater. Sci. Eng. C 62, 656-661. doi:10.1016/ j.msec.2016.02.011

Marambio-Jones, C., and Hoek, E. M. V. (2010). A Review of the Antibacterial Effects of Silver Nanomaterials and Potential Implications for Human Health and the Environment. J. Nanopart Res. 12 (5), 1531-1551. doi:10.1007/s11051010-9900-y

Mariod, A. A., Matthäus, B., and Hussein, I. H. (2009). Chemical Characterization of the Seed and Antioxidant Activity of Various Parts of Salvadora Persica. J. Am. Oil Chem. Soc. 86 (9), 857-865. doi:10.1007/s11746-009-1422-3

Martins, N. C. T., Freire, C. S. R., Pinto, R. J. B., Fernandes, S. C. M., Pascoal Neto, C., Silvestre, A. J. D., et al. (2012). Electrostatic Assembly of Ag Nanoparticles onto Nanofibrillated Cellulose for Antibacterial Paper Products. Cellulose 19 (4), 1425-1436. doi:10.1007/s10570-012-9713-5

Matsuyama, K., Morotomi, K., Inoue, S., Nakashima, M., Nakashima, H., Okuyama, T., et al. (2019). Antibacterial and Antifungal Properties of Ag Nanoparticle-Loaded Cellulose Nanofiber Aerogels Prepared by Supercritical CO2 Drying. J. Supercrit. Fluids 143, 1-7. doi:10.1016/j.supflu.2018.08.008

Mehrabani, M. G., Karimian, R., Mehramouz, B., Rahimi, M., and Kafil, H. S. (2018a). Preparation of Biocompatible and Biodegradable Silk Fibroin/chitin/ silver Nanoparticles 3D Scaffolds as a Bandage for Antimicrobial Wound Dressing. Int. J. Biol. macromolecules 114, 961-971. doi:10.1016/ j.ijbiomac.2018.03.128

Mehrabani, M. G., Karimian, R., Rakhshaei, R., Pakdel, F., Eslami, H., Fakhrzadeh, V., et al. (2018b). Chitin/silk fibroin/TiO2 Bio-Nanocomposite as a Biocompatible Wound Dressing Bandage with strong Antimicrobial Activity. Int. J. Biol. macromolecules 116, 966-976. doi:10.1016/ j.ijbiomac.2018.05.102

Missoum, K., Belgacem, M., and Bras, J. (2013). Nanofibrillated Cellulose Surface Modification: a Review. Materials 6 (5), 1745-1766. doi:10.3390/ma6051745

Mogoşanu, G. D., and Grumezescu, A. M. (2014). Natural and Synthetic Polymers for Wounds and burns Dressing. Int. J. Pharm. 463 (2), 127-136. doi:10.1016/ j.ijpharm.2013.12.015

Moohan, J., Stewart, S. A., Espinosa, E., Rosal, A., Rodríguez, A., Larrañeta, E., et al. (2020). Cellulose Nanofibers and Other Biopolymers for Biomedical Applications. A Review. Appl. Sci. 10 (1), 65. doi:10.1201/9781315368863-10

Moon, R. J., Martini, A., Nairn, J., Simonsen, J., and Youngblood, J. (2011). Cellulose Nanomaterials Review: Structure, Properties and Nanocomposites. Chem. Soc. Rev. 40 (7), 3941-3994. doi:10.1039/c0cs00108b

Mukhopadhyay, A., Basak, S., Das, J. K., Medda, S. K., Chattopadhyay, K., and De, G. (2010). Ag-TiO2 Nanoparticle Codoped $\mathrm{SiO} 2$ Films on ZrO2 BarrierCoated Glass Substrates with Antibacterial Activity in Ambient Condition. ACS Appl. Mater. Inter. 2 (9), 2540-2546. doi:10.1021/am100363d

Niño-Martínez, N., Martínez-Castañón, G. A., Aragón-Piña, A., MartínezGutierrez, F., Martínez-Mendoza, J. R., and Ruiz, F. (2008). Characterization of Silver Nanoparticles Synthesized on Titanium Dioxide fine Particles. Nanotechnology 19 (6), 065711. doi:10.1088/0957-4484/19/6/065711

Nishino, T. (2017). "Cellulose Fiber/nanofiber from Natural Sources Including Waste-Based Sources," in Green Composites (Elsevier), 19-38. doi:10.1016/ b978-0-08-100783-9.00010-1

Noumi, E., Snoussi, M., Merghni, A., Nazzaro, F., Quindós, G., Akdamar, G., et al. (2017). Phytochemical Composition, Anti-biofilm and Anti-Quorum Sensing Potential of Fruit, Stem and Leaves of Salvadora Persica L. Methanolic Extracts. Microb. Pathogenesis 109, 169-176. doi:10.1016/j.micpath.2017.05.036

Oun, A. A., and Rhim, J.-W. (2017). Preparation of Multifunctional Chitin nanowhiskers/ZnO-Ag NPs and Their Effect on the Properties of Carboxymethyl Cellulose-Based Nanocomposite Film. Carbohydr. Polym. 169, 467-479. doi:10.1016/j.carbpol.2017.04.042

Pandey, A. (2021). Pharmaceutical and Biomedical Applications of Cellulose Nanofibers: a Review. Environ. Chem. Lett. 19, 1-13. doi:10.1007/s10311021-01182-2

Phan, D.-N., Dorjjugder, N., Khan, M. Q., Saito, Y., Taguchi, G., Lee, H., et al. (2019). Synthesis and Attachment of Silver and Copper Nanoparticles on
Cellulose Nanofibers and Comparative Antibacterial Study. Cellulose 26 (11), 6629-6640. doi:10.1007/s10570-019-02542-6

Poonguzhali, R., Basha, S. K., and Kumari, V. S. (2017). Synthesis and Characterization of Chitosan-PVP-Nanocellulose Composites for In-Vitro Wound Dressing Application. Int. J. Biol. macromolecules 105, 111-120. doi:10.1016/j.ijbiomac.2017.07.006

Posada, P., Velásquez-Cock, J., Gómez-Hoyos, C., Guerra, A. S., Lyulin, S., Kenny, J., et al. (2020). Drying and Redispersion of Plant Cellulose Nanofibers for Industrial Applications: a Review. Cellulose 27, 1-22. doi:10.1007/s10570-02003348-7

Radhakumary, C., Antonty, M., and Sreenivasan, K. (2011). Drug Loaded Thermoresponsive and Cytocompatible Chitosan Based Hydrogel as a Potential Wound Dressing. Carbohydr. Polym. 83 (2), 705-713. doi:10.1016/ j.carbpol.2010.08.042

Rashki, S., Asgarpour, K., Tarrahimofrad, H., Hashemipour, M., Ebrahimi, M. S., Fathizadeh, H., et al. (2020). "Chitosan-based Nanoparticles against Bacterial Infections," in Carbohydrate Polymers, 117108.

Ribeiro, R. S. A., Pohlmann, B. C., Calado, V., Bojorge, N., and Pereira, N., Jr (2019). Production of Nanocellulose by Enzymatic Hydrolysis: Trends and Challenges. Eng. Life Sci. 19 (4), 279-291. doi:10.1002/elsc.201800158

Rojas, J., Bedoya, M., and Ciro, Y. (2015). "Current Trends in the Production of Cellulose Nanoparticles and Nanocomposites for Biomedical Applications," in Cellulose-fundamental Aspects and Current Trends. doi:10.5772/61334

Saini, S., Belgacem, M. N., and Bras, J. (2017). Effect of Variable Aminoalkyl Chains on Chemical Grafting of Cellulose Nanofiber and Their Antimicrobial Activity. Mater. Sci. Eng. C 75, 760-768. doi:10.1016/j.msec.2017.02.062

Saini, S., Belgacem, N., Mendes, J., Elegir, G., and Bras, J. (2015). Contact Antimicrobial Surface Obtained by Chemical Grafting of Microfibrillated Cellulose in Aqueous Solution Limiting Antibiotic Release. ACS Appl. Mater. Inter. 7 (32), 18076-18085. doi:10.1021/acsami.5b04938

Sampaio, L. M. P., Padrão, J., Faria, J., Silva, J. P., Silva, C. J., Dourado, F., et al. (2016). Laccase Immobilization on Bacterial Nanocellulose Membranes: Antimicrobial, Kinetic and Stability Properties. Carbohydr. Polym. 145, 1-12. doi:10.1016/j.carbpol.2016.03.009

Seery, M. K., George, R., Floris, P., and Pillai, S. C. (2007). Silver Doped Titanium Dioxide Nanomaterials for Enhanced Visible Light Photocatalysis. J. Photochem. Photobiol. A: Chem. 189 (2-3), 258-263. doi:10.1016/ j.jphotochem.2007.02.010

Shin, J. U., Gwon, J., Lee, S.-Y., and Yoo, H. S. (2018). Silver-incorporated Nanocellulose Fibers for Antibacterial Hydrogels. ACS omega 3 (11), 16150-16157. doi:10.1021/acsomega.8b02180

Singla, R., Soni, S., Patial, V., Kulurkar, P. M., Kumari, A., S, M., et al. (2017). Cytocompatible Anti-microbial Dressings of Syzygium Cumini Cellulose Nanocrystals Decorated with Silver Nanoparticles Accelerate Acute and Diabetic Wound Healing. Sci. Rep. 7 (1), 10457-10513. doi:10.1038/s41598017-08897-9

Song, H.-Z., Luo, Z.-Q., Wang, C.-Z., Hao, X.-F., and Gao, J.-G. (2013). Preparation and Characterization of Bionanocomposite Fiber Based on Cellulose and Nano$\mathrm{SiO} 2$ Using Ionic Liquid. Carbohydr. Polym. 98 (1), 161-167. doi:10.1016/ j.carbpol.2013.05.079

Strong, P. J., and Claus, H. (2011). Laccase: a Review of its Past and its Future in Bioremediation. Crit. Rev. Environ. Sci. Tech. 41 (4), 373-434. doi:10.1080/ 10643380902945706

Sulaiman, S., Mokhtar, M. N., Naim, M. N., Baharuddin, A. S., and Sulaiman, A. (2015). A Review: Potential Usage of Cellulose Nanofibers (CNF) for Enzyme Immobilization via Covalent Interactions. Appl. Biochem. Biotechnol. 175 (4), 1817-1842. doi:10.1007/s12010-014-1417-x

Szymańska-Chargot, M., Chylińska, M., Pertile, G., Pieczywek, P. M., Cieślak, K. J., Zdunek, A., et al. (2019). Influence of Chitosan Addition on the Mechanical and Antibacterial Properties of Carrot Cellulose Nanofibre Film. Cellulose 26 (18), 9613-9629. doi:10.1007/s10570-019-02755-9

Tang, Y., Zhang, X., Zhao, R., Guo, D., and Zhang, J. (2018). Preparation and Properties of Chitosan/guar Gum/nanocrystalline Cellulose Nanocomposite Films. Carbohydr. Polym. 197, 128-136. doi:10.1016/j.carbpol.2018.05.073

Tavakolian, M., Jafari, S. M., and van de Ven, T. G. M. (2020). A Review on SurfaceFunctionalized Cellulosic Nanostructures as Biocompatible Antibacterial Materials. Nanomicro Lett. 12 (1), 73-23. doi:10.1007/s40820-020-0408-4 
Tavakolian, M., Okshevsky, M., van de Ven, T. G. M., and Tufenkji, N. (2018). Developing Antibacterial Nanocrystalline Cellulose Using Natural Antibacterial Agents. ACS Appl. Mater. Inter. 10 (40), 33827-33838. doi:10.1021/acsami.8b08770

Thallinger, B., Prasetyo, E. N., Nyanhongo, G. S., and Guebitz, G. M. (2013). Antimicrobial Enzymes: an Emerging Strategy to Fight Microbes and Microbial Biofilms. Biotechnol. J. 8 (1), 97-109. doi:10.1002/biot.201200313

Thomas, S., Paul, S. A., Pothan, L. A., and Deepa, B. (2011). Natural Fibres: Structure, Properties and Applications. Cellulose Fibers: Bio-And Nano-Polymer Composites. Springer, 3-42. doi:10.1007/978-3-642-17370-7_1

Ullah, M. W., Manan, S., Ul-Islam, M., Revin, V. V., Thomas, S., and Yang, G. (2021). Introduction to Nanocellulose. Nanocellulose: Synthesis, Structure, Properties and Applications. World Scientific, 1-50. doi:10.1142/9781786349477_0001

Verdier, T., Coutand, M., Bertron, A., and Roques, C. (2014). Antibacterial Activity of $\mathrm{TiO} 2$ Photocatalyst Alone or in Coatings on E. coli: the Influence of Methodological Aspects. Coatings 4 (3), 670-686. doi:10.3390/coatings4030670

Wang, L., Hu, C., and Shao, L. (2017). The Antimicrobial Activity of Nanoparticles: Present Situation and Prospects for the Future. Ijn 12, 1227-1249. doi:10.2147/ ijn.s121956

Wang, P., Yin, B., Dong, H., Zhang, Y., Zhang, Y., Chen, R., et al. (2020). Coupling biocompatible au nanoclusters and cellulose nanofibrils to prepare the antibacterial nanocomposite films. Front. Bioeng. Biotechnol. 8, 986. doi:10.3389/fbioe.2020.00986

Wang, Z., Li, G., Peng, H., Zhang, Z., and Wang, X. (2005). Study on Novel Antibacterial High-Impact polystyrene/TiO2 Nanocomposites. J. Mater. Sci. 40 (24), 6433-6438. doi:10.1007/s10853-005-1713-5

Wu, J., Zheng, Y., Song, W., Luan, J., Wen, X., Wu, Z., et al. (2014). In Situ synthesis of Silver-Nanoparticles/bacterial Cellulose Composites for Slow-Released Antimicrobial Wound Dressing. Carbohydr. Polym. 102, 762-771. doi:10.1016/j.carbpol.2013.10.093

Zeng, J., Zeng, Z., Cheng, Z., Wang, Y., Wang, X., Wang, B., et al. (2021). Cellulose Nanofibrils Manufactured by Various Methods with Application as Paper Strength Additives. Scientific Rep. 11 (1), 1-16. doi:10.1038/s41598-021-91420-y
Zhang, J., Elder, T. J., Pu, Y., and Ragauskas, A. J. (2007). Facile Synthesis of Spherical Cellulose Nanoparticles. Carbohydr. Polym. 69 (3), 607-611. doi:10.1016/j.carbpol.2007.01.019

Zhang, K., Barhoum, A., Xiaoqing, C., Li, H., and Samyn, P. (2019). "Cellulose Nanofibers: Fabrication and Surface Functionalization Techniques," in Handbook of Nanofibers, 409-449. doi:10.1007/978-3-319-53655-2_58

Zhao, X., Wu, H., Guo, B., Dong, R., Qiu, Y., and Ma, P. X. (2017). Antibacterial Anti-oxidant Electroactive Injectable Hydrogel as Self-Healing Wound Dressing with Hemostasis and Adhesiveness for Cutaneous Wound Healing. Biomaterials 122, 34-47. doi:10.1016/j.biomaterials.2017.01.011

Zille, A., Almeida, L., Amorim, T., Carneiro, N., Esteves, M. F., Silva, C. J., et al. (2014). Application of Nanotechnology in Antimicrobial Finishing of Biomedical Textiles. Mater. Res. Express 1 (3), 032003. doi:10.1088/2053$1591 / 1 / 3 / 032003$

Conflict of Interest: The authors declare that the research was conducted in the absence of any commercial or financial relationships that could be construed as a potential conflict of interest.

Publisher's Note: All claims expressed in this article are solely those of the authors and do not necessarily represent those of their affiliated organizations, or those of the publisher, the editors and the reviewers. Any product that may be evaluated in this article, or claim that may be made by its manufacturer, is not guaranteed or endorsed by the publisher.

Copyright (C) 2021 Rashki, Shakour, Yousefi, Rezaei, Homayoonfal, Khabazian, Atyabi, Aslanbeigi, Safaei Lapavandani, Mazaheri, Hamblin and Mirzaei. This is an open-access article distributed under the terms of the Creative Commons Attribution License (CC BY). The use, distribution or reproduction in other forums is permitted, provided the original author(s) and the copyright owner(s) are credited and that the original publication in this journal is cited, in accordance with accepted academic practice. No use, distribution or reproduction is permitted which does not comply with these terms. 